\title{
Characterization of the South Atlantic marine boundary layer aerosol using an aerodyne aerosol mass spectrometer
}

\author{
S. R. Zorn ${ }^{1,2}$, F. Drewnick ${ }^{1}$, M. Schott ${ }^{3}$, T. Hoffmann ${ }^{3}$, and S. Borrmann ${ }^{1,2}$ \\ ${ }^{1}$ Max Planck Institute for Chemistry, Particle Chemistry Department, Mainz, Germany \\ ${ }^{2}$ University of Mainz, Institute for Atmospheric Physics, Mainz, Germany \\ ${ }^{3}$ University of Mainz, Institute of Inorganic and Analytical Chemistry, Mainz, Germany \\ Received: 31 January 2008 - Published in Atmos. Chem. Phys. Discuss.: 5 March 2008 \\ Revised: 23 June 2008 - Accepted: 23 July 2008 - Published: 18 August 2008
}

\begin{abstract}
Measurements of the submicron fraction of the atmospheric aerosol in the marine boundary layer were performed from January to March 2007 (Southern Hemisphere summer) onboard the French research vessel Marion Dufresne in the Southern Atlantic and Indian Ocean $\left(20^{\circ} \mathrm{S}-60^{\circ} \mathrm{S}, 70^{\circ} \mathrm{W}-60^{\circ} \mathrm{E}\right)$. We used an Aerodyne HighResolution-Time-of-Flight AMS to characterize the chemical composition and to measure species-resolved size distributions of non-refractory aerosol components in the submicron range.

Within the "standard" AMS compounds (ammonium, chloride, nitrate, sulfate, organics) "sulfate" is the dominant species in the marine boundary layer with concentrations ranging between $50 \mathrm{ng} \mathrm{m}^{-3}$ and $3 \mu \mathrm{g} \mathrm{m}^{-3}$. Furthermore, what is seen as "sulfate" by the AMS is likely comprised mostly of sulfuric acid.

Another sulfur containing species that is produced in marine environments is methanesulfonic acid (MSA). There have been previously measurements of MSA using an Aerodyne AMS. However, due to the use of an instrument equipped with a quadrupole detector with unit mass resolution it was not possible to physically separate MSA from other contributions to the same $m / z$. In order to identify MSA within the HR-ToF-AMS raw data and to extract mass concentrations for MSA from the field measurements the standard high-resolution MSA fragmentation patterns for the measurement conditions during the ship campaign (e.g. vaporizer temperature) needed to be determined.

To identify characteristic air masses and their source regions backwards trajectories were used and averaged concentrations for AMS standard compounds were calculated for
\end{abstract}

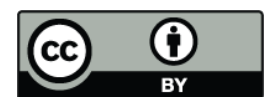

Correspondence to: S. R. Zorn (zorns@mpch-mainz.mpg.de) each air mass type. Sulfate mass size distributions were measured for these periods showing a distinct difference between oceanic air masses and those from African outflow. While the peak in the mass distribution was roughly at $250 \mathrm{~nm}$ (vacuum aerodynamic diameter) in marine air masses, it was shifted to $470 \mathrm{~nm}$ in African outflow air. Correlations between the mass concentrations of sulfate, organics and MSA show a narrow correlation for MSA with sulfate/sulfuric acid coming from the ocean, but not with continental sulfate.

\section{Introduction}

Although atmospheric research has become increasingly important in recent years, many processes taking place in the atmosphere are still barely understood (IPCC, 2007). This is particularly true for exchange of gases and particles between ocean and atmosphere, an area of study which is currently receiving much attention (Meskhidze and Nenes, 2006). Aerosol particles play an important role in the atmosphere because of their effects on the radiation budget and consequently on climate and climate change (Kolb, 2002), which is in particular true for aerosols from marine environments (O'Dowd et al., 2002). Currently, a focus is on their formation and understanding which gaseous compounds participate in it (O'Dowd et al., 2002).

The major source for marine boundary layer (MBL) aerosol particles in the super-micron size range is sea spray (Warneck, 1988), and consequently these particles are mainly composed of sodium chloride. However, under certain conditions a significant fraction of the sub-micron aerosol is of secondary origin, for example organic and inorganic sulfur compounds (Kerminen et al., 1997), but also other organic matter (O'Dowd et al., 2004). The mechanisms

Published by Copernicus Publications on behalf of the European Geosciences Union. 
leading to particle formation and growth from the gas phase (gas-to-particle conversion) are not yet fully understood (O'Dowd et al., 2002).

An important group of species which are quite common in atmospheric aerosol particles are sulfur compounds (Charlson et al., 1987), which participate in particle formation (Kulmala et al., 2002). These particles act as cloud condensation nuclei $(\mathrm{CCN})$ which are involved in tropospheric cloud formation, but are also important in polar stratospheric clouds which play a substantial role in stratospheric ozone depletion (Seinfeld and Pandis, 2006). As the ocean is a large natural source for atmospheric sulfur (Barnes et al., 2006), there is interest in understanding the pathway of aerosol formation of these compounds after being emitted from the ocean into the MBL.

Most of the sulfur in aerosol particles is available as sulfuric acid or, if neutralized, as sulfate. However, in coastal and oceanic environments sulfur is also present in organic compounds. One of the most common organic sulfur compounds within these environments is dimethylsulfide (DMS), which is produced by phytoplankton and several types of anaerobe bacteria (Charlson et al., 1987). DMS accounts for approximately $75 \%$ of the global sulfur cycle, with about 38 $40 \mathrm{Gg} \mathrm{yr}^{-1}$ of DMS released from the ocean into the atmosphere (Chasteen and Bentley, 2004). According to current understanding, after being emitted into the marine boundary layer, DMS will be oxidized mainly by hydroxyl radicals, resulting in a variety of products. Of these products dimethylsulfoxide (DMSO), dimethylsulfone $\left(\mathrm{DMSO}_{2}\right)$, and especially methanesulfonic acid (MSA) and sulfuric acid can be expected to partition into the particle phase (von Glasow and Crutzen, 2004).

Research on DMS oxidation products in the aerosol phase has been a major topic even before Charlson et al. (1987) published the CLAW hypothesis about a possible climate regulating effect due to the DMS sulfur cycle. One of the first measurements of MSA in maritime aerosols was performed by Saltzman et al. (1983), who identified and quantified MSA in filter samples collected in Miami (Florida), at Fanning Island and Midway Island (Pacific Ocean), and off the Somalian coast in the Indian Ocean, with concentrations ranging from $6 \mathrm{ng} \mathrm{m}^{-3}$ (Somalian Coast, in May 1979) up to $75 \mathrm{ng} \mathrm{m}^{-3}$ (Midway Island, May 1981). In later, regionally focused studies in the Pacific Ocean, Saltzman and coauthors (Saltzman et al., 1985, 1986) found average MSA concentrations between $10 \mathrm{ng} \mathrm{m}^{-3}$ (Norfolk Island, June to September 1983) and $170 \mathrm{ng} \mathrm{m}^{-3}$ (Shemya, May to September 1981). Offline measurements of MSA were also performed from samples taken in the sub-Antarctic and Antarctic Region at that time (Berresheim, 1987) showing mean MSA concentrations of $32 \mathrm{ng} \mathrm{m}^{-3}\left(0.33 \mathrm{nmol} \mathrm{m}^{-3}\right)$ for the Drake Passage and $18 \mathrm{ng} \mathrm{m}^{-3}\left(0.19 \mathrm{nmol} \mathrm{m}^{-3}\right)$ for the Gerlache Strait.
Measurements of MSA in aerosols were also reported by Watts et al. (1987), who found mean MSA concentrations of $89 \mathrm{ng} \mathrm{m}^{-3}$ during summer and $11 \mathrm{ng} \mathrm{m}^{-3}$ in the winter at a coastal site near Plymouth (Great Britain). These values are within the range of the previously mentioned MSA aerosol concentrations.

Bürgermeister and Georgii (1991) collected filter samples during two cruises covering the Atlantic Ocean from $42^{\circ} \mathrm{S}$ to $54^{\circ} \mathrm{N}$ and on a research platform in the North Sea with averaged MSA concentrations between 4 and $66 \mathrm{ng} \mathrm{m}^{-3}$ that showed a strong seasonal and geographical dependency of the sampling location. Similar results were found in other studies (Li et al., 1993, 1996) showing a variation of MSA in the aerosol phase between 2 and $200 \mathrm{ng} \mathrm{m}^{-3}$. Measurements at three different stations in the Antarctic (Minikin et al., 1998) also showed strong annual cycles of MSA with mean concentrations in summer 40 times higher than during winter.

Most of these measurements were performed off-line. However, during the second PARFORCE (New Particle Formation and Fate in the Coastal Environment) campaign (Mace Head, Ireland) Berresheim et al. (2002) used an online CIMS (chemical ionization mass spectrometry) system for measuring MSA in the coastal marine boundary layer.

Another application of on-line measurements in a marine environment took place during the 2002 SOLAS SERIES measurement campaign (July 2002). Phinney et al. (2006) used a Q-AMS to characterize the marine aerosol during an iron enrichment experiment in the sub-arctic Northern Pacific, including measurements of MSA mass concentrations.

Investigation of the marine aerosol formation is one aim of the OOMPH project (Organics over the Ocean Modifying Particles in both hemispheres, Sixth Framework Programme of the European Union). It is known that certain marine microorganisms produce not only DMS but also other organic compounds that can be released into the atmosphere and participate in aerosol formation (Berresheim, 1987; O'Dowd et al., 2004; Meskhidze and Nenes, 2006).

To characterize the aerosol in the remote and mostly pristine marine boundary layer within that project, we operated an Aerodyne High-Resolution Time-of-Flight Aerosol Mass Spectrometer (HR-ToF-AMS) during a ship campaign in the Southern Atlantic and Indian Ocean.

Unlike the original Aerodyne AMS (Q-AMS, Jayne et al., 2000) that uses a quadrupole mass spectrometer with unit mass resolution for ion analysis, the AMS used in this experiment is equipped with a Time-of-Flight mass spectrometer. Currently there are two versions of the ToF-AMS: the compact Time-of-Flight AMS (c-ToF-AMS, Drewnick et al., 2005), with a mass resolution up to $1200 \mathrm{~m} / \Delta \mathrm{m}$, and the HR-ToF-AMS (DeCarlo et al., 2006), which can be run in "V-mode" with a mass resolution of up to $3000 \mathrm{~m} / \Delta \mathrm{m}$ or in "W-mode" by using a second reflectron, which increases resolution to $6000 \mathrm{~m} / \Delta \mathrm{m}$ but decreases sensitivity by approximately one order of magnitude. The HR-ToF-AMS delivers 
quantitative data on non-refractory aerosol composition and species-resolved aerosol size distributions for the sub-micron particle size range. With its high sensitivity, the HR-ToFAMS is well suited for aerosol measurements in clean environments, like the remote marine boundary layer. The good temporal resolution of the data allows removal of measurements contaminated by ship exhaust without losing excessive amounts of information. Because of the expected low concentrations within the pristine marine boundary layer, the instrument was only operated in V-mode during the campaign.

Besides the study by Phinney et al. (2006), mentioned above, several applications of aerosol mass spectrometry for the analysis of the marine boundary layer aerosol have been reported previously. Gieray et al. (1997) used LAMMS (Laser microprobe mass spectrometry) for the analysis of individual aerosol particles collected in marine influenced clouds at Great Dunn Fell (Cumbria, UK). They found not only cloud droplets nucleated on sea salt particles but also cloud droplets formed on sulfate and methane sulfonate containing particles.

During the First Aerosol Characterization Experiment (ACE 1) in 1995, Murphy et al. (1998) used a laser ablation aerosol mass spectrometer (PALMS) stationed at Cape Grimm (Tasmania) for on-line analysis of individual aerosol particles. Sea salt could be found in $90 \%$ of the particle spectra, although data also showed indications of MSA in sulfate-dominated particles. Topping et al. (2004) used an Aerodyne AMS stationed at the Island of Jeju (Korea) for chemical characterization of the aerosol during the ACE Asia campaign. While the focus of this campaign was mainly the outflow from Asia, Topping et al. (2004) measured several marine influenced air masses that showed a strong variability and the highest AMS "sulfate" mass loadings during that period.

Another type of laser ablation aerosol mass spectrometer (ATOFMS) was used for on-line characterization of individual aerosol particles during the 2002 North Atlantic Marine Boundary Layer Experiment (NAMBLEX) at the remote marine site at Mace Head (Ireland), but Dall'Osto et al. (2004) focused their analysis on sea salt, dust and carbonaceous particles rather than sulfate. However, during this campaign also an Aerodyne AMS was used at the same site by Coe et al. (2006). One significant outcome of the NAMBLEX campaign was the observation that the submicron fraction of the measured marine aerosol was dominated by sulfate and organics with little contributions from sea salt and that sea salt dominated the coarse mode.

For the 2002 New England air quality study an Aerodyne AMS was installed aboard a ship (Bates et al., 2005). The focus of these measurements was the chemical characterization of the outflow from New England (USA), and not of marine aerosol components.

Here we present results from one of the first uses of an on-line aerosol mass spectrometer for measuring the chemical aerosol composition of the remote marine boundary layer

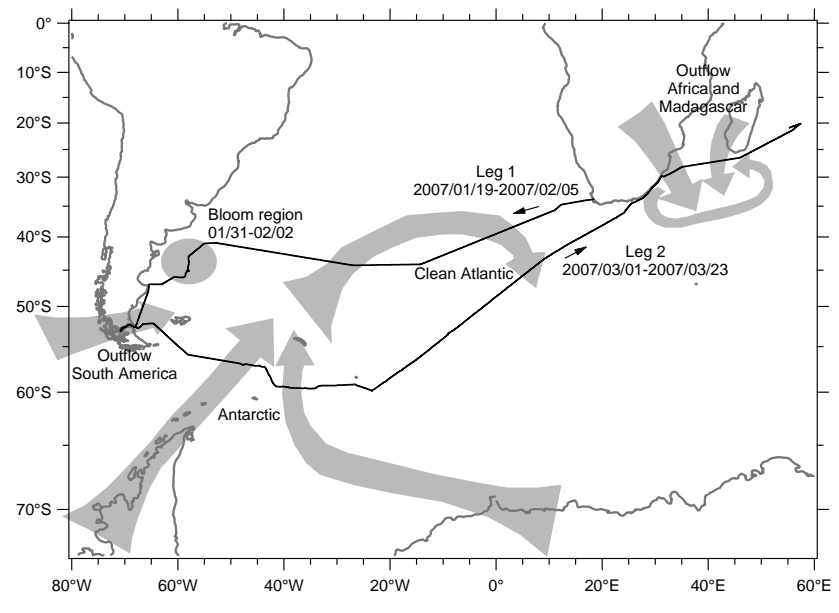

Fig. 1. Itinerary of the OOMPH 2007 Southern Hemisphere cruise. Large arrows show course of air masses for the selected time periods.

in the Southern Hemisphere. For the first time, MSA concentrations are directly determined from the high-resolution mass spectra. Furthermore, as the instrument was deployed on a ship crossing the Southern Atlantic Ocean, our measurements cover a large spatial area of the Southern Hemisphere.

\section{Overview over the 2007 OOMPH Southern Hemi- sphere cruise}

The measurements of MBL aerosol were taken during the 2007 OOMPH Southern Hemisphere cruise in the $20^{\circ} \mathrm{S}$ to $60^{\circ} \mathrm{S}$ latitude band. The OOMPH project is investigating the organic chemistry of the ocean and the marine boundary layer with a focus on organic vapors and their influence on particle nucleation processes. The cruise onboard the French research vessel Marion Dufresne took place in the Southern Atlantic Ocean and the Indian Ocean in the late Southern Hemisphere summer and early fall from January to March 2007 (Fig. 1). The campaign was split into two parts, hereafter called leg 1 and leg 2 .

Leg 1 started on the 19 January 2007 in Cape Town (South Africa). The ship crossed the Atlantic Ocean staying between $35^{\circ} \mathrm{S}$ and $45^{\circ} \mathrm{S}$ latitude. Upon arrival at the coast of South America, the course shifted south towards the Strait of Magellan. In this area two phytoplankton blooms were crossed (31 January 2007-2 February $2007,40^{\circ} \mathrm{S}-45^{\circ} \mathrm{S}$, $\left.55^{\circ} \mathrm{W}\right)$. After passing the Strait of Magellan the ship arrived on 5 February 2007 in Punta Arenas (Chile) ending leg 1.

On the 1 March 2007 the ship left Punta Arenas heading south for leg 2 (Fig. 1). This time the ship cruised southeastwards near $60^{\circ} \mathrm{S}$ latitude until 9 March, when it passed $24^{\circ} \mathrm{W}$ longitude. From that point on it headed northeast towards Durban (South Africa). After arriving near Durban 


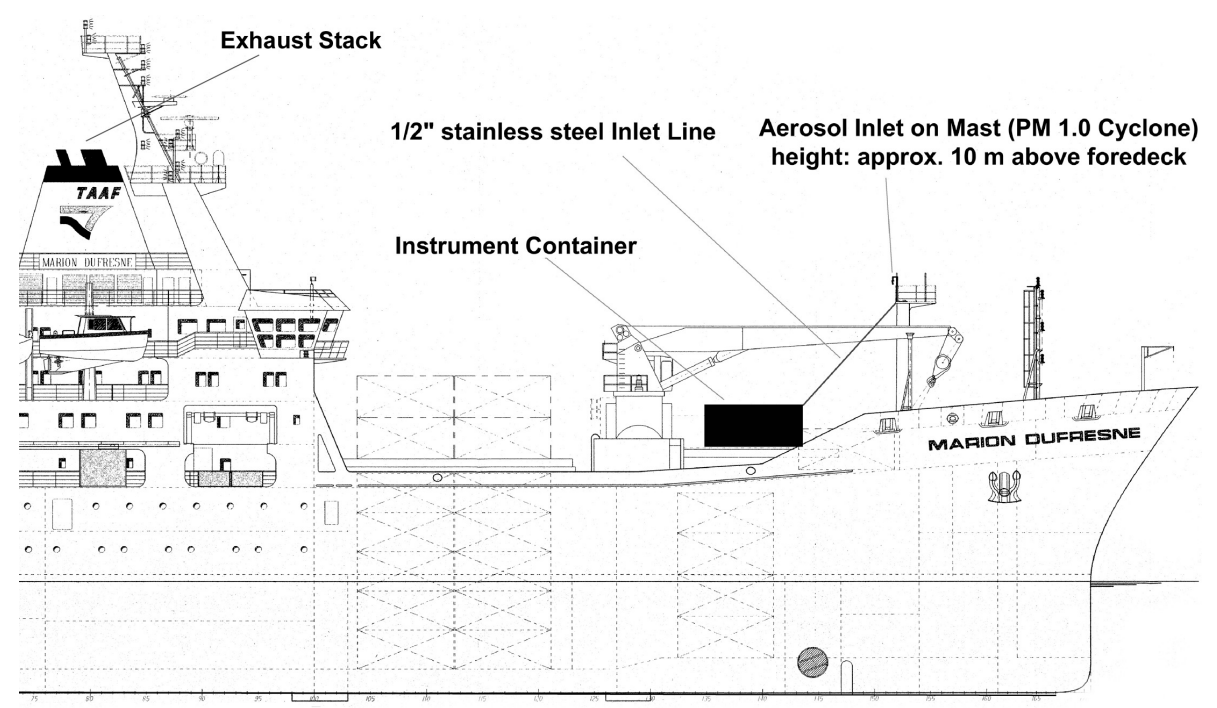

Fig. 2. Position and setup of the aerosol inlet and measurement container.

on 18 March 2007, the ship proceeded towards the Mascarene Islands (Reunion, Mauritius). The campaign ended on 23 March 2007 near Reunion Island.

The measurements during the 2007 Southern Hemisphere campaign included a wide range of parameters. The most common meteorological parameters were taken including sounding balloons; LIDAR measurements, but also flux measurements and calculations of air flow dynamics and turbulences around the ship and the inlets and probe systems were performed. Oceanic monitoring included sampling of seawater several times a day for biological characterization as well as the determination of chemical and physical parameters, such as sea salinity, surface temperature and $\mathrm{CO}_{2}$ concentrations. Gas phase measurements included ozone, $\mathrm{OH}$, $\mathrm{HO}_{2}, \mathrm{RO}_{2}$ and $\mathrm{NO}_{\mathrm{x}}$ concentrations as well as organic species like DMS, isoprene and halocarbons. Additional air samples were also collected in electropolished stainless steel canisters for subsequent VOC analysis at least twice a day.

For the particle phase characterization of the MBL, filter samples were taken for chemical analysis as well as for morphological characterization by electron microscopy. Particle number concentrations and size distributions were measured by optical methods. The soluble part of the fine aerosol was measured with a Particle-into-Liquid-Sampler, coupled to an Ion Chromatograph (PILS-IC); the chemical composition of the non-refractory submicron aerosol was determined using the High-Resolution-Time-of-Flight AMS, whose results are the topic of the current publication.

\section{Instrumental setup and data quality assurance for the AMS}

The AMS was located inside an air conditioned container on the deck of the ship (Fig. 2). The aerosol was sampled with a $\mathrm{PM}_{1.0}$ cyclone (URG-2000-30EHB) on top of the aerosol mast at a height of $10 \mathrm{~m}$ above the foredeck and approximately $20-25 \mathrm{~m}$ above the sea surface. A $1 / 2^{\prime \prime}$ stainless steel sampling inlet line with a total length of $15 \mathrm{~m}$ ran from the aerosol inlet to the container. The inlet flow of the AMS during the campaign was $0.1 \mathrm{lpm}$. A critical orifice before a vacuum pump maintained a steady total flow rate of $16.7 \mathrm{lpm}$ through the inlet line, resulting in an average flow velocity of approximately $4.5 \mathrm{~m} \mathrm{~s}^{-1}$ and a retention time of $3.5 \mathrm{~s}$ for particles within the inlet line. Simple calculations for transport losses according to Hinds (1998) show that for the particle size range between $40 \mathrm{~nm}$ and $1000 \mathrm{~nm}$, losses are below two percent. The AMS sample flow was extracted from the inlet line using an isokinetic sampling probe immediately before the AMS inlet and was not dried prior to sampling.

To ensure data quality calibrations were performed several times during the campaign. A particle-Time-of-Flight calibration to convert the particle flight times into particle diameters was performed once at the beginning of the campaign, just after the instrument was installed inside the container. To determine the instrument background and instrumentspecific parameters, measurements through a high efficiencyparticulate air filter (HEPA filter) were performed two times during the campaign (once during each leg). The ionization efficiency of the ion source was quantified at the beginning and at the end of each leg, and the sensitivity of the detector was monitored continuously and calibrated at least once a week. 
Table 1. ToF-AMS instrument performance during the OOMPH 2007 Southern Hemisphere cruise.

\begin{tabular}{lllllll}
\hline & Downtimes & \multicolumn{3}{l}{ Operation times } \\
\hline & Calibrations & $\begin{array}{l}\text { Instrumental } \\
\text { failures }\end{array}$ & $\begin{array}{l}\text { Total } \\
\text { downtime }\end{array}$ & $\begin{array}{l}\text { Contaminated } \\
\text { by stack }\end{array}$ & $\begin{array}{l}\text { Clean } \\
\text { data }\end{array}$ & $\begin{array}{l}\text { Total } \\
\text { uptime }\end{array}$ \\
\hline $\begin{array}{l}\text { Leg 1 } \\
\text { 19 Jan-5 Feb }\end{array}$ & $\begin{array}{l}09: 10 \mathrm{~h} \\
2.3 \%\end{array}$ & $\begin{array}{l}00: 00 \mathrm{~h} \\
0.0 \%\end{array}$ & $\begin{array}{l}09: 10 \mathrm{~h} \\
2.3 \%\end{array}$ & $\begin{array}{l}19: 20 \mathrm{~h} \\
4.7 \%\end{array}$ & $\begin{array}{l}378: 40 \mathrm{~h} \\
93.0 \%\end{array}$ & $\begin{array}{l}398: 00 \mathrm{~h} \\
97.7 \%\end{array}$ \\
Leg 2 & $4: 10 \mathrm{~h}$ & $68: 20 \mathrm{~h}$ & $72: 30 \mathrm{~h}$ & $119: 25 \mathrm{~h}$ & $327: 30 \mathrm{~h}$ & $446: 55 \mathrm{~h}$ \\
1 March-23 March & $0.8 \%$ & $13.2 \%$ & $14.0 \%$ & $23.0 \%$ & $63.0 \%$ & $86.0 \%$ \\
\hline
\end{tabular}

To correct for reduced aerosol collection efficiency as a consequence of incomplete transmission of the particles to the vaporizer, as well as for particle bounce from the vaporizer before evaporation, the AMS analysis software corrects the measured mass concentrations with the so-called Collection Efficiency factor, CE (Huffman et al., 2005). This factor can be determined by comparing AMS measurements with those from other instruments, such as a PILS-IC. Under typical continental conditions the AMS collection efficiency is about $50 \%$. Typically this value is rationalized by the supposition that approximately $50 \%$ of the particles bounce off the vaporizer before they evaporate. For liquid particles, including pure ammonium nitrate, DOP (dioctyl phthalate) particles or activated particles under very humid conditions, the collection efficiency increases to almost $100 \%$ (Allan et al., 2004; Quinn et al., 2006; Matthew et al., 2008).

For the OOMPH campaign, the time series for ToF-AMS "sulfate" mass concentrations show a good correlation with the preliminary nss-sulfate (non sea salt sulfate) time series measured by the PILS-IC (J. Sciare, personal communication, manuscript in preparation), where ss-sulfate (sea salt sulfate) has been subtracted from total sulfate. The comparison of the two measurements shows an agreement for sulfate mass concentrations within $6 \%$ without applying a collection efficiency correction for AMS "sulfate".

This suggests that the particles were mostly liquid leading to the conclusion that they either had a significant liquid surface layer as a consequence of the large RH or they were comprised of a large fraction of sulfuric acid. The latter assumption is supported by a simple calculation of sulfate neutralization using the measured ammonium and "sulfate" mass concentrations. According to these calculations, during most pristine periods only a minor fraction (20-50\%) of the sulfate can be neutralized by ammonium. Only when air masses were continentally influenced or when sulfate concentrations were close to the detection limit for ammonium was a neutralization in the order of 100 percent possible.

As a consequence of these findings, no collection efficiency factor was applied to correct for particle bounce for the aerosol concentrations presented in this paper.
During regular operation the instrument collected averaged high resolution mass spectra, species-resolved size distributions and single particle spectra by alternating through these three operation modes. The instrument spent $40 \%$ of the time collecting average mass spectra and averaged size distributions and $20 \%$ collecting single particle data. A sampling period was ten minutes long during the first part of the cruise crossing the Atlantic Ocean from East to West. For the second part of the cruise, the averaging time was decreased to five minutes to reduce the amount of measurement intervals lost because of short contamination events by the ship's stack emissions, which were much more pronounced during leg 2 going from West to East.

The measurements for the first part of the campaign were started on 19 January 2007 while the ship was still in the harbor. The instrument collected data during the whole time of leg 1 without any problems until arrival of the ship in Punta Arenas on the 5th of February. Measurements for leg 2 were started on the 1 March 2007 before leaving the harbor of Punta Arenas. During this leg some instrumental problems occurred. As a result of a failure of the vaporizer power supply, the instrument did not run for approximately three days in the beginning of leg 2 .

The measurements ended on 23 March 2007, when the Marion Dufresne was heading towards Reunion Island. A summary of calibrations, downtimes and operation times as well as stack contamination and clean data for the two legs is shown in Table 1.

\section{Extraction of MSA concentrations from AMS data}

This is the first time that an AMS has been used to measure remote marine aerosols in the Southern Hemisphere. Since the standard AMS data processing (Allan et al., 2004) does not include methanesulfonic acid (MSA), a substance to be found ubiquitously in aerosol particles from marine environments, a procedure had to be developed to separate MSA from "sulfate" and "organics" in the AMS mass spectra and to quantify this species. Phinney et al. (2006) developed a procedure to extract MSA concentrations from unit-resolution Q-AMS data using laboratory standard 

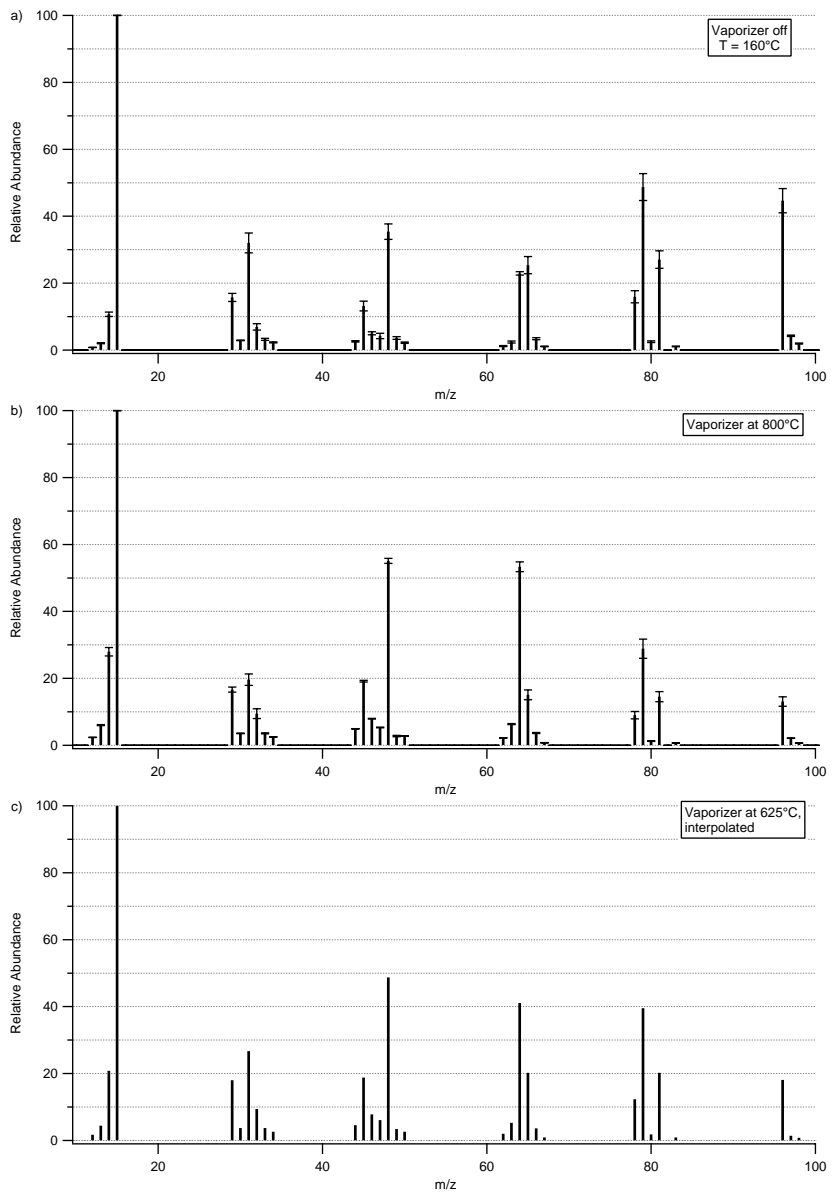

Fig. 3. Fragmentation pattern for MSA at a vaporizer temperature of $160^{\circ} \mathrm{C}$ (panel a), at $800^{\circ} \mathrm{C}$ (panel b) and at $625^{\circ} \mathrm{C}$ (panel c), normalized to the most prominent peak $(\mathrm{m} / \mathrm{z}, 15)$. The error bars are the standard deviation over 12 measurements. Generally a trend from larger $\mathrm{m} / \mathrm{z}$ signals towards smaller $\mathrm{m} / \mathrm{z}$ signals is observed with increasing vaporizer temperature. Panel (c) is the interpolated fragmentation pattern for the actual vaporizer temperature during the measurements using the patterns for the individual $\mathrm{m} / \mathrm{z}$, shown in Table 2.

fragmentation patterns and assumptions about the $m / z 79$ signal contributions, while our method provides a more direct identification of the MSA-related signal using the highresolution information of the HR-ToF-AMS. As a first step in achieving this aim comprehensive laboratory experiments were performed to characterize the fragmentation of MSA in the AMS evaporation and ionization process and to determine MSA fragmentation patterns that can be used for field data analysis.

The aerosol was generated by nebulizing a solution of MSA (Sigma-Aldrich, purity $>=99.5 \%$ ) in water with an atomizer (TSI, Model 3076). The aerosol was dried through two silica gel dryers before being introduced into the AMS where standard mass spectra of this species were recorded.
To test if MSA could still be seen and separated from other compounds, a combined solution of MSA and ammonium sulfate $\left(\left(\mathrm{NH}_{4}\right)_{2} \mathrm{SO}_{4}\right)$ was tested. In order to be able to predict the MSA fragmentation pattern in AMS measurements at all vaporizer temperatures standard fragmentation patterns were determined for a series of fifteen different vaporizer temperatures ranging from $160^{\circ} \mathrm{C}$ up to $800^{\circ} \mathrm{C}$. The lowest temperature was reached by turning vaporizer heating completely off. The remaining vaporizer temperature of approximately $160^{\circ} \mathrm{C}$ is due to radiative heating by the electron emitting filament of the ToF-AMS ion source. In order to achieve good statistics and to account for potential day-to-day variations, temperature dependencies were measured three times on different days with at least four averaging intervals of five minutes each.

These experiments show that the fragmentation pattern of MSA is heavily dependent on the vaporizer temperature (Fig. 3). Comparison with the NIST spectrum for MSA (NIST Mass Spec Data Center, 2005, data not shown) demonstrates similar patterns for AMS and reference spectra at low vaporizer temperatures (Fig. 3a). The differences that can still be seen between the measured spectrum and the NIST spectrum are due to two reasons. The first reason is that the vaporizer temperature of the AMS is well above the minimum necessary temperature for evaporation of MSA, which leads to increased fragmentation of the molecules. Second, the NIST spectrum starts with higher mass-to-charge ratios while AMS spectra are normally recorded starting with $m / z 12$, which makes it possible to record the methylfragments $(\mathrm{m} / \mathrm{z}, 12-15)$ and to identify the most prominent MSA fragment at $m / z 15$.

Generally, higher vaporizer temperatures lead to a shift to smaller mass-to-charge ratios in the fragmentation pattern (Fig. 3b). Especially the peak of the parent ion at $m / z 96$ and the fragments at $m / z 78,79$ and 81 decrease quite strongly whereas signals at $m / z 14,48$ and 64 increase. The reason for this is most likely thermal decomposition during the flashvaporization process or thermally induced enhancement of fragmentation in the electron impact ionization process.

The individual MSA fragments were grouped into 7 sets that showed similar relative peak intensity dependence of vaporizer temperature (Table 2). To be able to predict the average MSA fragmentation pattern at any given temperature, for each of the main fragments a fit for the temperature dependency was calculated using equations that describe the peak intensity dependence sketched in Table 2 . Using these fits it is possible to calculate the specific fragmentation pattern for any vaporizer temperature between $160^{\circ} \mathrm{C}$ and $800^{\circ} \mathrm{C}$. The variability for some fragments within the measurements at individual vaporizer temperatures (error bars in Fig. 3) shows that some fragments are influenced by external parameters like humidity, ambient temperature and possibly concentration of MSA of the spray solution.

The fragmentation pattern characterization shows that most fragments of MSA occur at $\mathrm{m} / \mathrm{z}$ values where fragments 
of sulfate and sulfuric acid or of other organic species can also be found. Therefore, in order to extract MSA-related signals, these fragments must be separated from those of the AMS "sulfate" and "organics". Due to the small relative uncertainty of the individual line intensities of the various fragments (Fig. 3) and the knowledge of the MSA fragmentation pattern at each vaporizer temperature, it is sufficient to know the intensity of one of the major fragments in order to reconstruct the entire MSA fragmentation pattern.

As the most suitable one for such a characteristic fragment the signal at $m / z 79\left(\mathrm{CH}_{3} \mathrm{SO}_{2}{ }^{+}\right)$was identified for two reasons. This fragment is not only one of the most prominent MSA fragments containing a sulfur atom, but also it can be found at a $\mathrm{m} / \mathrm{z}$ where no fragment from the sulfate or sulfuric acid fragmentation pattern is present. Unlike the Q-AMS used by Phinney et al. (2006), which provides only mass spectra with unit mass resolution, the HR-ToF-AMS is in principle capable of collecting mass spectra with mass resolution up to $6000 \mathrm{~m} / \Delta \mathrm{m}$, making it possible to separate the MSA fragment at $m / z 79\left(\mathrm{CH}_{3} \mathrm{SO}_{2}{ }^{+}\right.$, 78.99) from the other major contributors at this $m / z$, bromine $\left(\mathrm{Br}^{+}, m / z\right.$ 78.92) and a hydrocarbon organic fragment $\left(\mathrm{C}_{6} \mathrm{H}_{7}{ }^{+}, m / z 79.06\right)$. Therefore, with this instrument, MSA can be quantified directly from the contribution of the MSA fragment to $m / z 79$ only, without correcting the MSA signals using assumptions about the non-MSA components at the same $\mathrm{m} / \mathrm{z}$.

Due to the large differences in the exact masses of the species found at $m / z 79$ they can also be separated at the mass resolution of $\mathrm{m} / \Delta \mathrm{m}=2500$ at which the HR-ToF-AMS was operated during the ship measurement campaign. This was not necessarily possible for the other MSA fragments.

To extract the MSA signal intensity at $\mathrm{m} / \mathrm{z} 79$ a three-step algorithm was implemented in the raw mass spectra integration of the ToF-AMS Data Analyzer TADA (Hings et al., 2007), which was used to process the campaign data. Since the instrument had been used for experiments on halogens in aerosols before the campaign, which tend to remain in the ionization chamber for a long time, the bromine peak $(\mathrm{m} / \mathrm{z}$ 78.92) was always present in the background spectra of the instrument, unlike the MSA peak. Therefore, it was used to perform a very exact mass calibration by fitting a simple Gaussian distribution at this part of the high resolution background mass spectra at $m / z 79$ (Fig. 4). The second step was fitting a function consisting of three Gaussian distributions to the whole $m / z 79$ signal of the aerosol mass spectrum. For this fit the width of each of the three Gaussian functions was held constant and set to match the mass resolution of the instrument at this $\mathrm{m} / \mathrm{z}$. In addition the center points of the three Gaussian distributions were held constant at the locations calculated from the exact mass calibrations for the three species. Therefore only the amplitudes of the three peaks at $\mathrm{m} / \mathrm{z} 79$ were fitted using the Marquardt-Levenberg algorithm, implemented into IGOR Pro (Wavemetrics), the platform on which TADA runs.
Table 2. Patterns for temperature-dependence of the signal of the main MSA fragments. (Pictograms: signal intensity versus vaporizer temperature, ranging from $160^{\circ} \mathrm{C}$ to $800^{\circ} \mathrm{C}$ ).

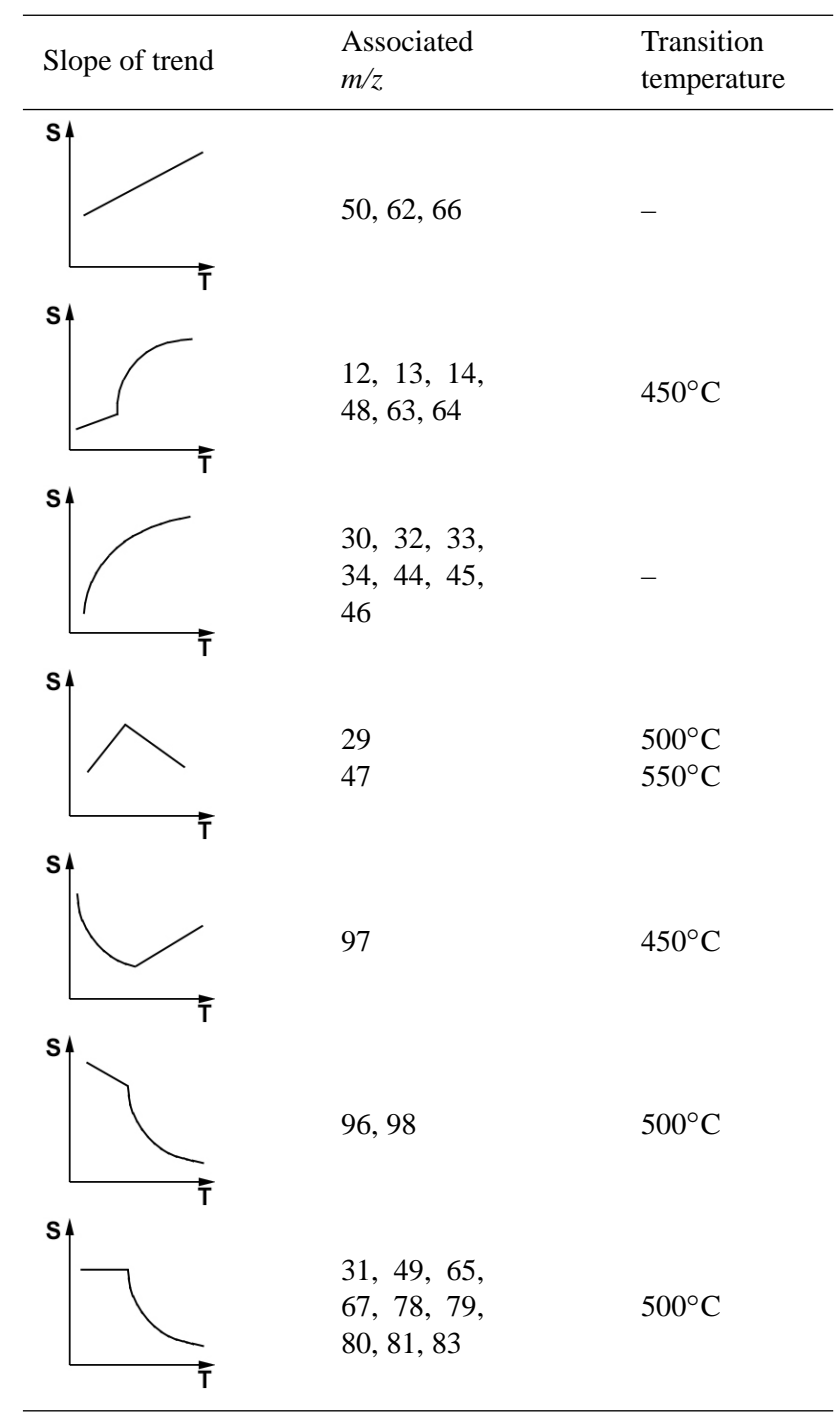

With these premises and restrictions, the amplitude of each of the three Gaussian functions gives the fraction of the associated peak of the total peak at $m / z 79$. Therefore the fit can be used to determine not only the MSA fraction, but also the organic and bromine part of the $\mathrm{m} / \mathrm{z} 79$ signal. Since the method described uses only the MSA fraction of the whole $m / z 79$ mass peak of the spectrum, it provides significantly lower limits of detection $\left(900 \mathrm{pg} \mathrm{m}^{-3}\right.$ for total MSA) than one would obtain using conventional AMS data analysis as used by Phinney et al. (2006) who reported $\mathrm{LOD}_{\mathrm{MSA}}=17 \mathrm{ng} \mathrm{m}^{-3}$.

With the MSA fraction identified and quantified at $\mathrm{m} / \mathrm{z} 79$ and the fragmentation pattern derived from the laboratory experiments one can now calculate the intensity for each MSA fragment in each aerosol mass spectrum and subtract it from 


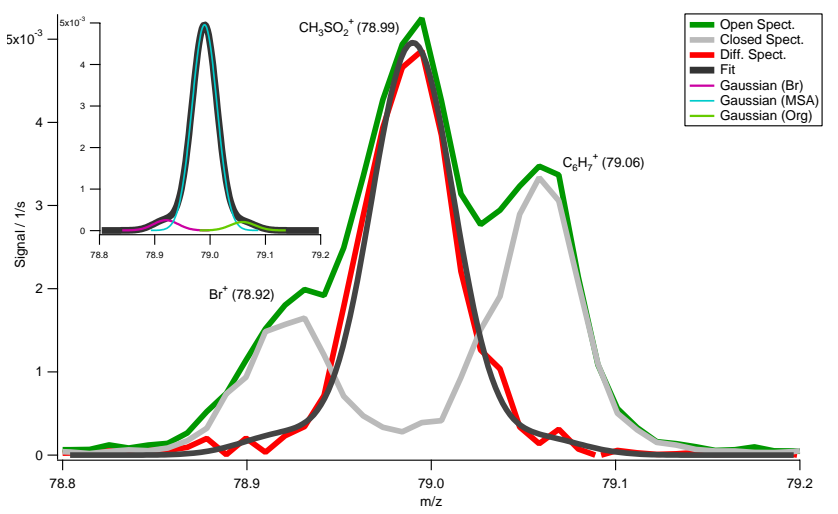

Fig. 4. Extraction of $m / z 79$ MSA signal: Three Gaussian distributions are fitted to the exact $\mathrm{m} / \mathrm{z}$ of the three main contributors to this $m / z$. "Open Spect." is the spectrum recorded by the instrument when measuring the aerosol beam, "Closed Spect." the instrumental background with the aerosol beam blocked. The resulting mass spectrum is obtained by subtracting the background spectrum from the aerosol spectrum.

the according $\mathrm{m} / \mathrm{z}$. After this calculation MSA no longer contributes to the mass fragments of AMS "sulfate" and "organics".

To calculate the mass concentrations for MSA during the field measurements the vaporizer temperature dependent fits (Table 2) were used to calculate the contribution of each fragment to the total MSA mass concentration for the vaporizer temperature used during the ship measurement campaign ( $T=625^{\circ} \mathrm{C}$, see Fig. $3 \mathrm{c}$ ). To convert the resulting $\mathrm{NO}_{3}$ equivalent mass concentration into actual species mass concentrations, another parameter, the relative ionization efficiency RIE (Drewnick et al., 2005) for MSA, must be applied. Due to the fact that MSA has a large vapor pressure and MSA particles quickly evaporate under typical laboratory conditions (temperature, $\mathrm{RH}, \mathrm{MSA}$ vapor mixing ratio), it was not possible to determine the MSA relative ionization

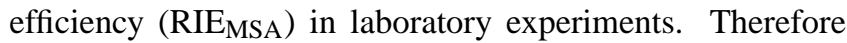
RIE $_{\text {MSA }}$ was calculated from the RIE of sulfate and organics using Eq. (1) as a best estimate.

$$
\begin{aligned}
\operatorname{RIE}_{\mathrm{MSA}} & =\frac{\left(\mathrm{RIE}_{\mathrm{Org}}+\mathrm{RIE}_{\mathrm{SO}_{4}}\right)}{2} \\
\Rightarrow \mathrm{RIE}_{\mathrm{MSA}} & =\frac{(1.4+1.2)}{2}=1.3
\end{aligned}
$$

This estimate can lead to a significant error since the RIE is proportional to the mass concentration of the compound. So far, it is the best assumption we can provide since no MSA concentrations measured by other instruments during the campaign are available. Our estimate for RIE $_{\text {MSA }}$ is different from the value used by Phinney et al. (2006), who used the same RIE for this species as they used for sulfate $\left(\mathrm{RIE}_{\mathrm{MSA}}=\mathrm{RIE}_{\mathrm{SO}_{4}}=1.15\right)$.
This method for MSA extraction presented above can be applied for any measurements taken with a HR-ToF-AMS as long as excessive signal from other species at $\mathrm{m} / \mathrm{z} 79$ does not inhibit MSA peak separation. The resolution provided by a c-ToF-AMS is not sufficient to clearly separate the individual peaks at this $\mathrm{m} / \mathrm{z}$.

Our mass calibration for these three peaks was based on the bromine peak in the background spectra. Since the instrument used during the campaign was involved in a number of laboratory experiments dealing with halogens before the campaign, it is unclear if the amount of bromine that one would get from environmental measurements would be sufficient to perform exactly the same fit procedure. However, since the variation within the mass calibration of the AMS is quite small and does not change within a few $\mathrm{m} / \mathrm{z}$, we recommend the use of a nearby peak present at all times, such as the sulfate peak at $m / z 80$, for the first mass calibration if the bromine peak at $m / z 79$ is missing or too low.

\section{Field data analysis}

\subsection{Removing exhaust contamination}

During a ship campaign, the ship's own exhaust is always a potential source of contamination for most atmospheric measurements. While constant wind directions can support the contamination-free sampling using well positioned sampling inlets, it can also lead to a significant fraction of contaminated samples, especially if the ship has to pursue a narrow schedule and the sampling points are fixed.

As the ship was travelling from East to West during leg 1, wind was coming from ahead most of the times. With the ToF-AMS sampling inlet being located on the aerosol mast $\sim 10 \mathrm{~m}$ above the foredeck of the ship, contamination from the stack was very rare for this part of the campaign. In total, less than five percent of the collected data from leg 1 showed exhaust signatures (Table 1). For leg 2, the situation was quite different because the ship was traveling in the opposite direction. This resulted in extended time periods with winds coming from the back of the ship, bringing exhaust from the stack, located in the middle of the ship (Fig. 2), to the sampling inlet installed on the bow. To keep measurement times lost due to contamination as low as possible without losing too much information, the ToF-AMS averaging length was decreased from ten to five minutes for this leg. Still approximately $120 \mathrm{~h}(23 \%)$ of data were contaminated in leg 2 .

To reliably exclude the contaminated data from the dataset before further analysis, measurement data were filtered and time intervals with exhaust were removed. This was done by using a variety of criteria based on AMS and wind data. The criteria for data exclusion were observations of wind speed amplitude and direction ranges relative to the ships movement, in which the ToF-AMS data showed signs of exhaust contamination. Exhaust contamination was 


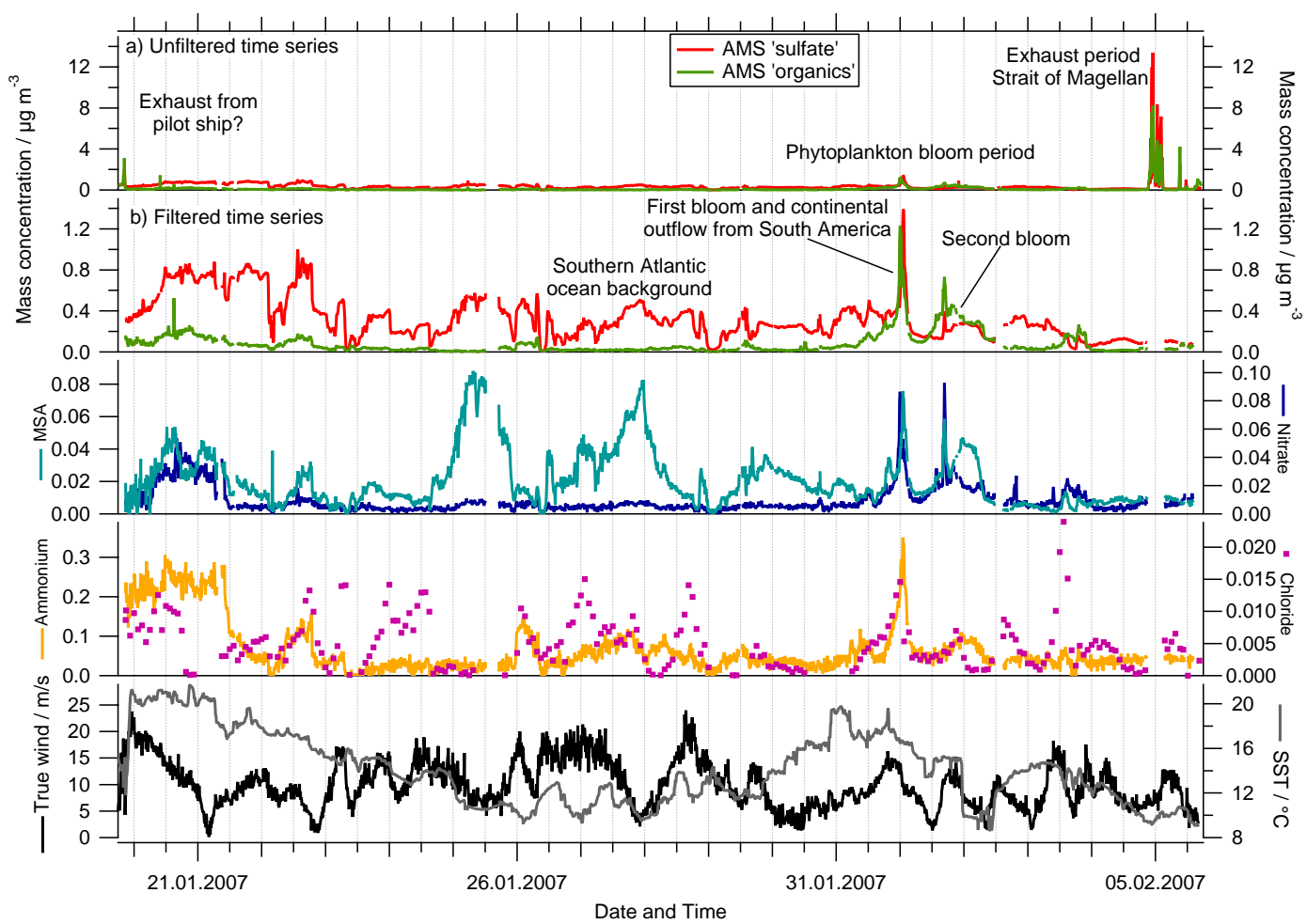

Fig. 5. Unfiltered ("sulfate" and "organics", top) and filtered ("sulfate", "organics", MSA, nitrate, ammonium and chloride) time series for

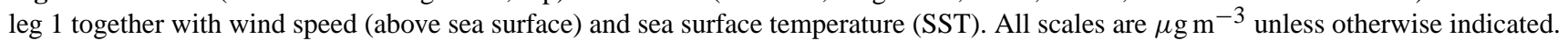

generally observed when the relative wind speed dropped below $2 \mathrm{~m} \mathrm{~s}^{-1}$, but also when the wind was coming from a sector between $135^{\circ}$ and $215^{\circ}$ relative to the ship $\left(0^{\circ}\right.$ is in the front, $180^{\circ}$ in the back). In addition ToF-AMS mass concentration and size distribution signatures for "sulfate" and "organics" were used to identify contaminated data. In the ToF-AMS data these events showed a high, simultaneous increase in "sulfate" and "organics" mass concentrations, as well as an additional mode between 40 and $100 \mathrm{~nm}$ particle diameter in the aerosol size distributions. In Figs. 5 and 6 the effect of the filter applied to the ToF-AMS mass concentration time series is presented for both legs.

As has been mentioned before and can be seen in Fig. 5, during leg 1 only a few short time intervals were contaminated by the ship exhaust. During these events mass concentrations of "sulfate" and "organics" increased by at least one order of magnitude.

In addition to the downtimes of the instrument at the beginning of leg 2 (see Table 1), contamination of measurements with stack exhaust occurred quite frequently during leg 2. Interestingly, the signatures for the exhaust events are always the same (characterized by a strong increase in AMS "organics" and "sulfate"), but the intensities vary. Looking closely at Fig. 6 it seems that for the exhaust events the organics-to-sulfate ratio decreases over the course of the campaign. Possible explanations for this behavior are the influence of external parameters like air temperature and humidity or wind speed. Another reason could be a change in the composition of the remaining fuel over the course of the campaign

Another potential way to remove exhaust signatures from AMS measurements is a method to separate hydrocarbonlike organic aerosols (HOA) produced by combustion from oxygenated organic aerosols (OOA) mainly of biological origin (Zhang et al., 2005). This method was developed for aerosol in urban environments, where both organic components are found at reasonable concentrations. Since this is not the case for our measurements this method cannot be used. A first examination shows typical HOA-like spectra only for exhaust periods. For all other times the spectra are not similar to common HOA or OOA spectra (Zhang et al., 2005), and require a deeper analysis, which is not within the scope of this paper.

\subsection{Time series of aerosol mass concentrations}

Looking at the filtered time series of the uncontaminated measurements some points are quite obvious. First AMS "sulfate" is nearly always the dominating species in the fraction of the marine aerosol measured by the AMS, i.e. the submicron non-refractory aerosol (Figs. 5 and 6). Only when 


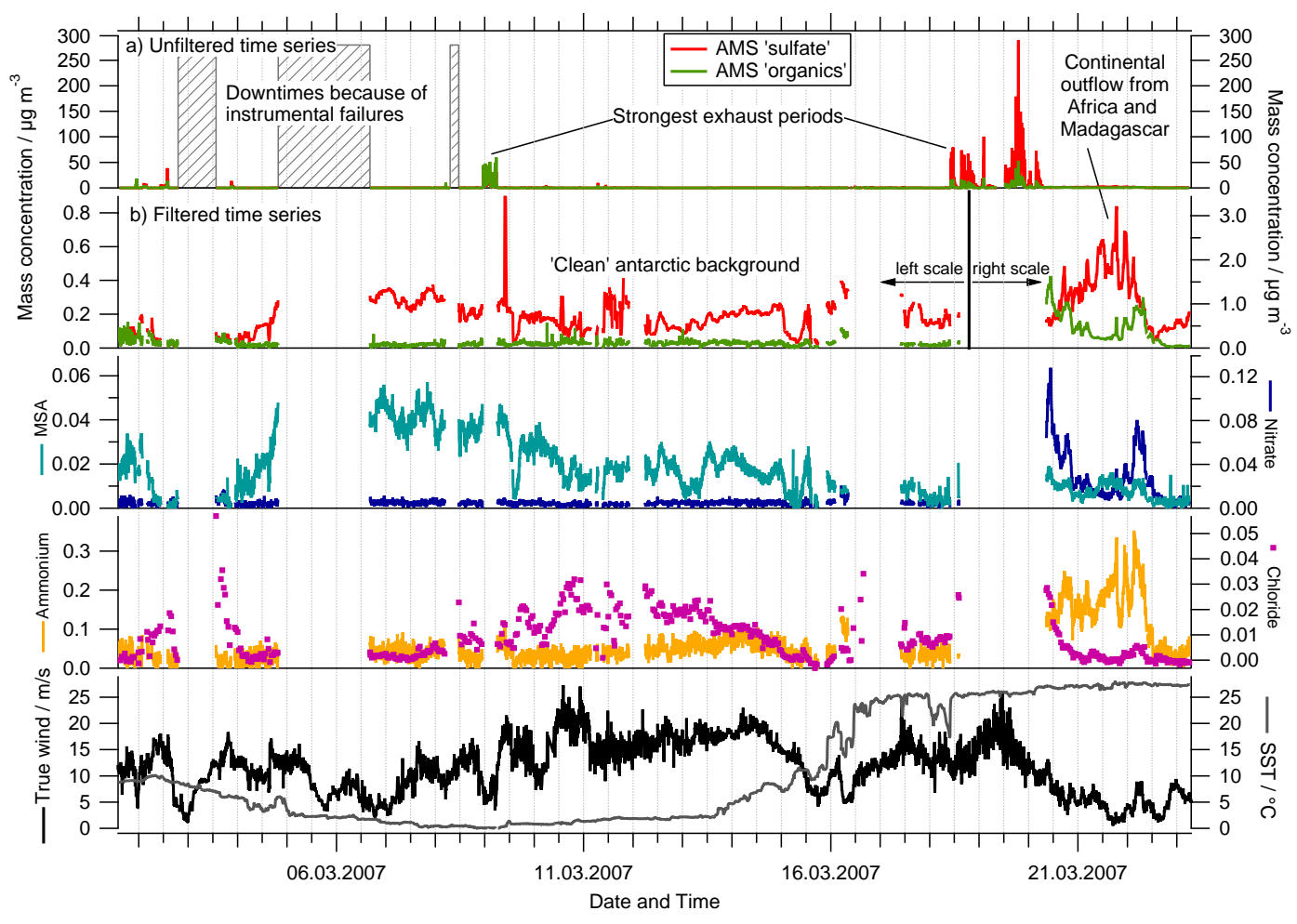

Fig. 6. Unfiltered ("sulfate" and "organics", top) and filtered ("sulfate", "organics", MSA, nitrate, ammonium and chloride) time series for leg 2 together with wind speed (above sea surface) and sea surface temperature (SST). All scales are $\mu \mathrm{g} \mathrm{m}^{-3}$ unless otherwise indicated.

coming close to coastal areas or when passing through one of the phytoplankton blooms did organic concentrations exceed those of AMS "sulfate". The blooms in that region are caused by the Malvinas Current, a branch of the Antarctic Circumpolar Current flowing northwards along the continental shelf of Chile and Argentina (Legeckis and Gordon, 1998; Garzoli, 1993) bringing nutrient-rich, cold water $\left(6^{\circ} \mathrm{C} \mathrm{SST}\right)$ with it (Brandini et al., 2000). The blooms were identified by satellite data and an increased biological activity was seen by the strong green color of the ocean. For both bloom events a drop in sea surface temperature (SST) can be seen (Fig. 5, bottom), especially for the second event in which SST drops from $16^{\circ} \mathrm{C}$ to $10^{\circ} \mathrm{C}$, indicating the inflow of cold water. During these bloom periods "organics" contribute up to 50 percent to the total non-refractory aerosol mass concentrations in the size fraction below $1 \mu \mathrm{m}$.

The temporal trends of the time series for methanesulfonic acid (Fig. 5 and 6) follow those for AMS "sulfate" for times where the aerosol is mainly dominated by marine sources. This is because both, methanesulfonic acid and sulfate, originate from the same source, oxidation of dimethylsulfide (DMS), and because there is no additional sulfate from other sources during the most pristine periods.
For leg 1, generally the ratio between MSA and AMS "sulfate" is higher when air masses did come directly from Antarctica (24 January 2007-25 January 2007, 26 January 2007-28 January 2007) and during the phytoplankton bloom periods near South America, especially during the second bloom (1 February 2007-2 February 2007). For periods when air masses were coming from the middle of the ocean or had a long residence time there before arriving at the ship (Clean Atlantic, 12 March 2007-15 March 2007), the ratio is much lower. However, the trends for MSA and AMS "sulfate" time series are still similar, possibly due to longer transport from the source region to the ship or due to the later season.

Only for the time after passing the phytoplankton bloom region when - according to backward trajectories (see below) - air masses were continentally influenced by passing over South America and inside the Strait of Magellan, this is no longer true. For these time intervals, MSA is nearly zero, although the time series for AMS "sulfate" show significant concentrations.

During leg 2 the typical mass concentrations of AMS "sulfate" and MSA were only half as large as the ones from leg 1 , possibly because of lower temperatures (Fig. 6) and the transition from summer to autumn in the Southern Hemisphere leading to reduced biological activity. Total organic mass 
Table 3. Averaged mass concentrations for the most common species measured during the OOMPH 2007 cruise within different air masses.

\begin{tabular}{|c|c|c|c|c|c|c|c|}
\hline Originated from & $\begin{array}{l}\mathrm{SO}_{4} \\
\mu \mathrm{g} \mathrm{m}^{-3}\end{array}$ & $\begin{array}{l}\mathrm{NH}_{4} \\
\mu \mathrm{g} \mathrm{m}^{-3}\end{array}$ & $\begin{array}{l}\mathrm{NO}_{3} \\
\mu \mathrm{g} \mathrm{m}^{-3}\end{array}$ & $\begin{array}{l}\text { Org. } \\
\mu \mathrm{g} \mathrm{m}^{-3}\end{array}$ & $\begin{array}{l}\text { Chl. } \\
\mu \mathrm{g} \mathrm{m}^{-3}\end{array}$ & $\begin{array}{l}\text { MSA } \\
\mu \mathrm{g} \mathrm{m}^{-3}\end{array}$ & $\begin{array}{l}\text { Total } \\
\mu \mathrm{g} \mathrm{m}^{-3}\end{array}$ \\
\hline Antarctic & 0.31 & 0.05 & 0.01 & 0.02 & $<0.01$ & 0.04 & 0.43 \\
\hline (80:10 $\mathrm{h}$ average) & $72 \%$ & $12 \%$ & $2 \%$ & $5 \%$ & $<1 \%$ & $9 \%$ & $100 \%$ \\
\hline Bloom & 0.21 & 0.07 & 0.02 & 0.32 & $<0.01$ & 0.03 & 0.65 \\
\hline ( $22: 10 \mathrm{~h}$ average) & $32 \%$ & $11 \%$ & $3 \%$ & $49 \%$ & $<1 \%$ & $5 \%$ & $100 \%$ \\
\hline Clean Atlantic & 0.18 & 0.06 & $<0.01$ & 0.03 & 0.01 & 0.02 & 0.30 \\
\hline (53:50 $\mathrm{h}$ average) & $60 \%$ & $20 \%$ & $<1 \%$ & $10 \%$ & $3 \%$ & $7 \%$ & $100 \%$ \\
\hline Outflow Africa & 1.39 & 0.18 & 0.04 & 0.56 & $<0.01$ & 0.01 & 2.18 \\
\hline (51:55 $\mathrm{h}$ average) & $64 \%$ & $8 \%$ & $2 \%$ & $26 \%$ & $<1 \%$ & $1 \%$ & $100 \%$ \\
\hline South America & 0.27 & 0.04 & 0.01 & 0.04 & 0.01 & $<0.01$ & 0.37 \\
\hline (22:40 $\mathrm{h}$ average) & $73 \%$ & $11 \%$ & $2 \%$ & $11 \%$ & $2 \%$ & $1 \%$ & $100 \%$ \\
\hline
\end{tabular}

concentrations (without MSA) in contrast to "sulfate" and MSA did not show such a difference. Their average mass concentration was within the same range as for leg 1, except the concentrations measured during the bloom period. Overall, during the second leg, not much variation was seen in the time series for AMS "organics", AMS "sulfate" and MSA. Only when the measurements were performed in a region with continental influence from Africa and Madagascar (20 March 2007-23 March 2007) could a strong change in both "organics" and "sulfate" mass concentrations be seen. Again the mass concentration for MSA did not rise during that period, which just represents the fact that MSA is produced only from oxidation of DMS released from the ocean (Berresheim, 1987; Mihalopoulos et al., 1992). This makes MSA an excellent tracer for marine aerosol in general and for marine biogenic sulfur emissions, as has been shown before (Saltzman et al., 1986; Li et al., 1993; Allen et al., 1997). From our laboratory experiments we know that pure MSA particles evaporate quickly. However, in a natural, mixed aerosol this seems to be different. Putaud et al. (1999) estimated a lifetime of approximately six days in the absence of precipitation. Millet et al. (2004) proposed an even longer lifetime of approximately 12 days for MSA, and Sodemann et al. (2006) found MSA on dust particles from alpine ice cores and linked it to a dust event going through a phytoplankton bloom area in the Mediterranean Sea.

During most periods of the ship cruise ammonium was close to the detection limit (LOD, $60 \mathrm{ng} \mathrm{m}^{-3}$ ) or below. Significant mass concentrations of ammonium could only be measured at the beginning of leg 1 (Fig. 5), and when air masses were continentally influenced by outflow from Africa (20 March 2007-23 March 2007, Fig. 6) when the average mass concentration of ammonium was $0.18 \mu \mathrm{g} \mathrm{m}^{-3}$. The high concentrations at the beginning of the cruise are most likely because of continental influence from Africa.
An increase of ammonium to a maximum of $0.35 \mu \mathrm{g} \mathrm{m}^{-3}$ also occurred during the first bloom period together with AMS "sulfate", which most likely is an indication of continental influence. During the second bloom event ammonium mass concentrations rose only slightly above the LOD resulting in an average mass concentration of $0.07 \mu \mathrm{g} \mathrm{m}^{-3}$.

Nitrate mass concentrations during the campaign were also quite low, but typically above the detection limit $\left(3 \mathrm{ng} \mathrm{m}^{-3}\right)$. Interestingly, nitrate mass concentrations also rose during the bloom period $\left(20 \mathrm{ng} \mathrm{m}^{-3}\right)$ as well as during the period in which outflow from Africa was observed with an average concentration of $40 \mathrm{ng} \mathrm{m}^{-3}$ (Fig. 6). Unlike ammonium, the nitrate concentration seems to be correlated with the concentration of AMS "organics". For all other times, when no continental influence can be seen, nitrate shows very low concentrations.

Since the AMS can only measure the non-refractory part of the sub-micron aerosol, it does not detect sodium chloride with significant efficiency. However, it is possible that a small fraction of the chloride from the sea salt can be detected, showing at least a trend for sea salt in the sub-micron fraction of the MBL aerosol. For leg 1, 10-min averaged chloride mass concentrations were almost always below the detection limit of $16 \mathrm{ng} \mathrm{m}^{-3}$. Despite being below the detection limit, the chloride time series showed clear structures. Thus the time series was averaged over $90 \mathrm{~min}$, reducing the detection limit for chloride by a factor of three to a value of approximately $5 \mathrm{ng} \mathrm{m}^{-3}$ (Fig. 5). For leg 2 an increase of chloride mass concentrations to about $20-30 \mathrm{ng} \mathrm{m}^{-3}$ can be seen between the 8 and the 15 March 2007 (Fig. 6), which does not correlate with any other substance measured by the AMS.

Comparison of the chloride time series with wind speed shows, for most structures within the chloride time series, a positive correlation for both legs (Figs. 5 and 6). Wind 


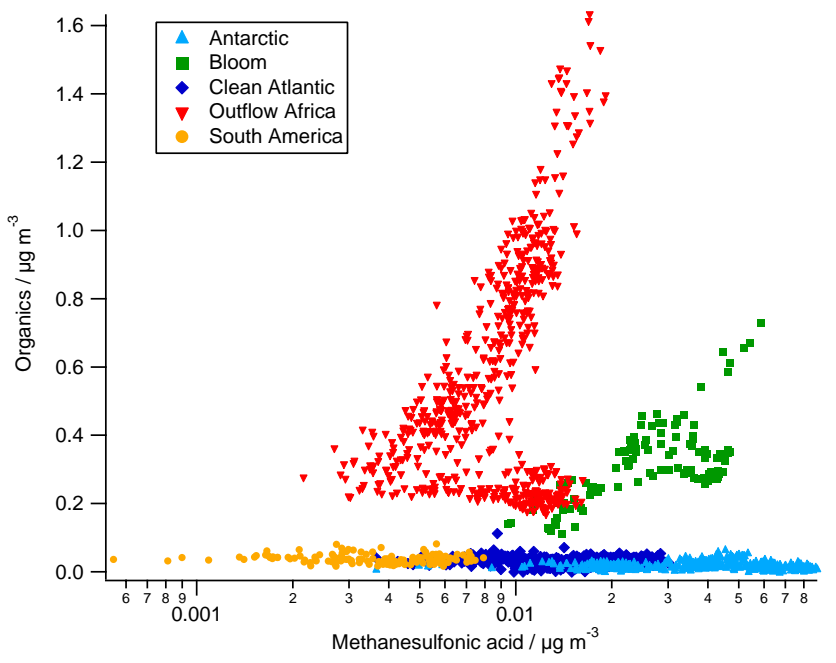

Fig. 7. Correlation of MSA with AMS "organics" for various air masses.

speed over ocean surface was calculated from apparent wind data and ship movement and orientation. The sea salt concentration within the submicron fraction of the MBL aerosol increases with increasing wind speeds, especially if wind speeds are above the values needed for whitecap formation (6-8 $\mathrm{m} \mathrm{s}^{-1}$ for a significant fraction of white cap coverage, $\mathrm{Wu}, 1979)$. This correlation indicates that the AMS, even though it is not capable of flash vaporizing sodium chloride, can provide some information about sea salt concentrations, at least under the conditions observed during this ship campaign.

The analysis so far indicates that AMS "sulfate" is the dominant species of the marine submicron non-refractory aerosol. Organic species contribute only to a minor degree to this aerosol composition in the MBL, but are present at all times (Table 3). In contrast, nitrate and ammonium are only found in the aerosol mass spectra close to the continents. During measurements of undisturbed marine air masses the concentration of these species is typically below the detection limit of $60 \mathrm{ng} \mathrm{m}^{-3}$ for ammonium and of $3 \mathrm{ng} \mathrm{m}^{-3}$ for nitrate - hence no ammonium and only very low concentrations of nitrate were detected in the submicron aerosol in the MBL. This means that no counter ion for the "sulfate" measured with the ToF-AMS is present during most periods on the ocean, and suggests that most of the ToF-AMS species class "sulfate" is sulfuric acid. The vaporization and ionization process in the ToF-AMS generates fragmentation patterns for sulfate and sulfuric acid that are very similar to each other, and at this time it is not possible to separate these two species using the standard AMS data processing method (Allan et al., 2004). In continental regions, sulfuric acid is rapidly neutralized because ammonia evaporating from soils or from other sources is available in sufficient concentrations

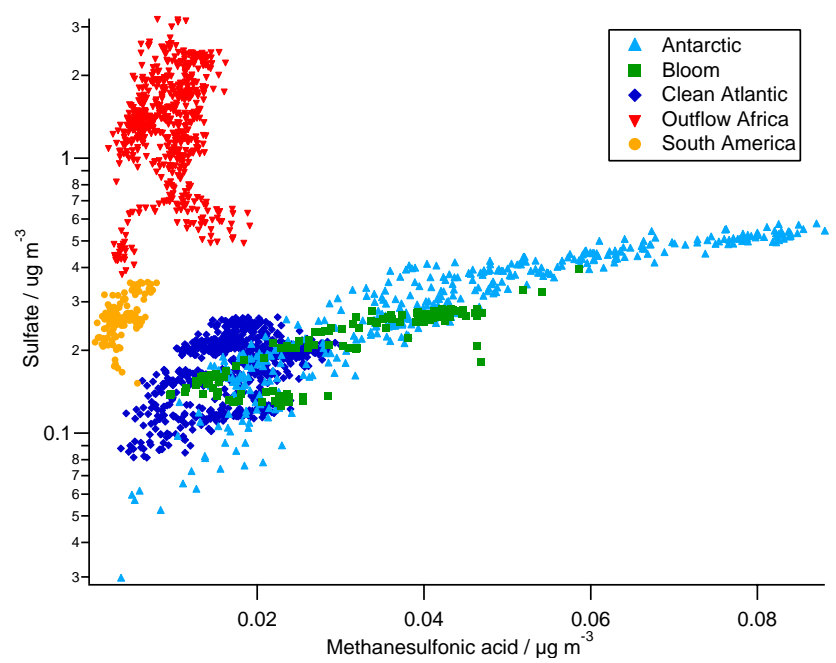

Fig. 8. Correlation of MSA with AMS "sulfate" for various air masses.

to produce ammonium sulfate. However, these sources are missing over the ocean. The assumption that particles contain a large fraction of sulfuric acid is supported by the PILSIC data collected during the campaign (J. Sciare, personal communication, manuscript in preparation).

\subsection{Aerosol characteristics of various air masses}

For further analysis of the ToF-AMS data and to characterize the composition and physical parameters of the aerosol found in different air masses observed during the ship cruise an analysis of these air masses based on backward trajectories was performed. The 10-day backward trajectories were calculated with the Lagrangian analysis tool (Wernli and Davies, 1997), using wind fields from operational ECMWF analysis data. Ensembles of 24 trajectories were calculated every three hours, with 24 starting points along the ship track for each time step.

To calculate average aerosol parameters for different air masses we looked for time intervals when air mass backtrajectories originated from the same source region, followed similar paths, and spent similar times within a certain region. If, for example, trajectories originally came from Antarctic regions but had a long residence time travelling over the Southern Atlantic Ocean for several days instead of going straight to the ship position, they were no longer treated as originating from Antarctica but as "Clean Atlantic". Using the criteria described above, five time periods representing different source regions were identified, hereafter called "Antarctic", "Bloom", "South America", "Clean Atlantic" and "Outflow Africa". Schematic arrows characterizing the back-trajectories, or originating regions in the case of the bloom period, of these air masses can be found in Fig. 1. 
For each of these time periods the origin and track of the trajectories stayed constant at least one day or longer, except for the "Bloom" period, which lasted only a few hours when the ship crossed through the phytoplankton bloom area. A summary of species concentrations measured with the ToFAMS for each of the air masses is presented in Table 3.

To investigate possible relations between different species for the different regions we calculated correlations between the most abundant species "sulfate", "organics", and MSA (Figs. 7 and 8).

To be classified as "Antarctic", air masses had to originate in, and come straight from Antarctica (3-5 days according to backward trajectories) before arriving at the ship position (Fig. 1). These air masses are characterized by very low concentrations for most aerosol compounds except "sulfate" and MSA. A large MSA-to-sulfate ratio is quite characteristic for these air masses as shown in the correlation plot for these species in Fig. 8. "organics" show lowest concentrations for this source region, leading to a very high MSA-to-organics ratio (Fig. 7).

The air masses characterized as "Clean Atlantic" are very similar to the "Antarctic" period (Table 3). Trajectories for these air masses also came originally from Antarctica but stayed for some days above the Southern Atlantic Ocean going from West to East before approaching the ship from the Northwest (5-10 days after passing Antarctica). "sulfate" and MSA show similar ratios for "Antarctic" air and "Clean Atlantic" air (Fig. 8), but concentrations are almost a factor of two lower for "Clean Atlantic". Chloride shows the highest concentrations for "Clean Atlantic" air masses, caused by high wind speeds for these air masses, leading to an increase of small sea salt particles even in the size range below $1 \mu \mathrm{m}$ (Figs. 5 and 6). Finally, the MSA-to-organics ratio is on the same correlation branch as for "Antarctic" air masses (Fig. 7). The strong similarities between "Clean Atlantic" and "Antarctic" aerosol composition suggests, that the "Antarctic" aerosol is also dominated by marine emissions collected during the short time the air spent traveling to the ship position or, alternatively, from emissions within the biological active Antarctic shelf region but not by emissions from the Antarctic continent itself.

When arriving in the costal region of South America, the ship passed through phytoplankton blooms. Phytoplankton blooms or algae blooms are areas in which the population of one or more species of micro algae or marine bacteria is increasing rapidly due to a strong nutrient input. These organisms are known to produce organic compounds which can be released into the atmosphere including DMS, halocarbons (Lovelock et al., 1973) and isoprene (Bonsang et al., 1992). As mentioned above the blooms were indicated by satellite images and the high biological activity that produced the green color of the ocean.

During the "Bloom" periods offshore of South America (Fig. 1) "sulfate" mass concentrations were at similar levels as for "Clean Atlantic" air masses, but concentrations for "organics" were significantly higher making up nearly 50 percent of the total non-refractory aerosol mass below one micrometer. Compared to the organic concentrations measured during "Antarctic" and "Clean Atlantic" periods, organic concentrations are approximately 20 times higher during the "Bloom". A detailed investigation of this organic aerosol is part of forthcoming analyses and beyond the scope of this paper.

In fact the bloom period is the only one when "organics" are clearly dominating the aerosol composition. Unfortunately, during this time interval air mass trajectories came from South America (first bloom event, see Fig. 5) and from the Pacific Ocean passing briefly over South America (second bloom event). Although for the second bloom event they were only passing over less populated areas of grassland (Patagonia), an influence from continental sources cannot be excluded.

The MSA-to-"sulfate" ratio for this period (Fig. 8) is similar to that for "Clean Atlantic", but the concentrations measured during the bloom are higher, although slightly below those for "Antarctic" air masses. Interestingly, the organicsto-MSA ratio for the bloom period differs drastically from that of the other two air masses. Another indication for continental influence during this period are the relatively high nitrate mass concentrations (Fig. 5). These are approximately twice as large as those observed in the "Clean Atlantic" and "Antarctic" air masses. On the other hand - according to the MSA-to-"sulfate" ratio - no significant "sulfate" influence from the continent can be seen in the data during the bloom, inconsistent with a major continental influence. However, from the current state of the data no final conclusion can be drawn.

The only time when nitrate concentrations are even higher than within the bloom aerosol is during the "Outflow Africa" period. Air masses measured during that period are coming primarily from the Southern Atlantic (for the first half) and Indian Ocean (second half), but most of them passed over Africa or Madagascar before arriving at the ships position and are clearly continentally influenced (Fig. 1), as "sulfate" concentrations are at maximum values for these periods. The same is true for mass concentrations of ammonium and the total non-refractory sub-micron aerosol concentration. At the same time MSA concentrations are the lowest observed within any of the air masses (Table 3). The correlation plot of "organics" and MSA (Fig. 7) shows a very large organics-toMSA ratio as well as a large "sulfate"-to-MSA ratio (Fig. 8). This is another indicator for the significant continental influence of the air masses observed during this time period.

The correlation plot (Fig. 7) for "organics" with MSA shows two modes for this period, the main one with a large organics-to-MSA ratio and a smaller one with a large MSAto-organics ratio. A detailed inspection of the backward trajectories for this time interval and the associated data points in Fig. 6 shows that at the beginning of this period the wind was coming from Northwest (Continental Africa). In the 


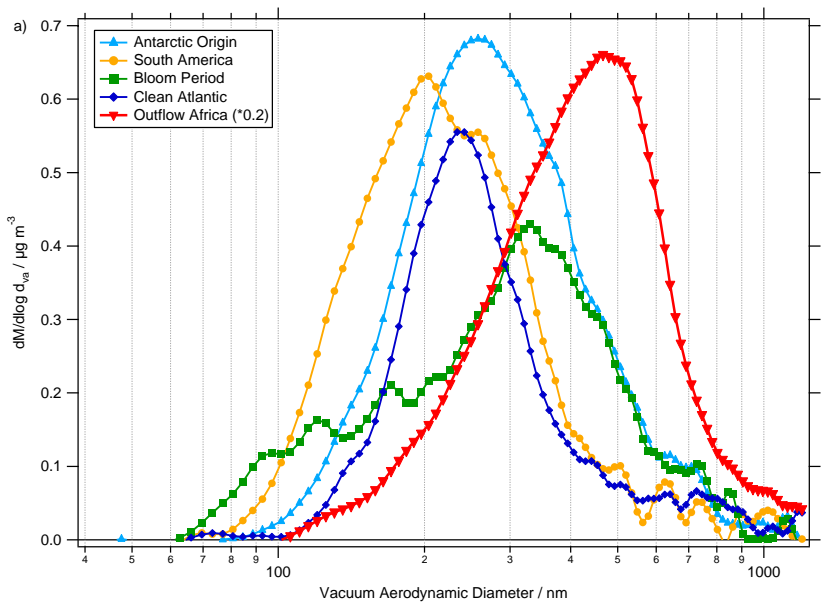

Fig. 9. Size distributions of AMS "sulfate" for the different air masses. Size distribution for "Outflow Africa" has been divided by five to scale with the other size distributions.

course of the ship passing from Africa to Madagascar the wind direction changed to South (Southern Atlantic/Indian Ocean) and later to North East (Madagascar). The data points for this second smaller mode are from this period of change, when mainly marine air masses with only little continental influence were observed. During the periods at the beginning and the end of the "Outflow Africa" interval the large continental influence was observed.

The only other time when the "sulfate"-to-MSA ratio shows a similar behavior with negligible MSA fraction is during the "South America" period. At that time the air masses measured originated from Pacific Antarctic regions and passed over the southern part of South America shortly before arriving at the ship. This period shows the lowest mass loading for MSA during the whole campaign, with values below $0.01 \mu \mathrm{g} \mathrm{m}^{-3}$. Whether this is due to a short MSA lifetime with respect to wet deposition occurring while passing over the Andes or due to lack of other reasons like missing sources for MSA is so far unknown.

The organics-to-MSA ratio during the "South America" period has the same slope as for "Antarctic" and "Clean Atlantic" air masses. The average mass concentration for "organics" during the "South America" period is two times higher than that for these two oceanic periods, but still ten times lower than the organic mass concentrations for the "Bloom" and "Outflow Africa" periods.

As shown in Figs. 7 and 8 "sulfate" and MSA as well as organics and MSA show compact correlations for the individual air masses, even though the absolute concentrations of these species vary significantly. For different air masses these correlations show very different slopes.

\subsection{AMS "sulfate" size distributions}

The concentrations for most compounds measured during the ship campaign are too low to generate meaningful particle size distributions for the non-refractory sub-micron aerosol. Only for sulfate or sulfuric acid, as discussed above, mass concentrations were high enough to provide sufficient signal for calculating averaged size distributions for the different time intervals associated with the different air masses as mentioned before (Fig. 9).

The size distributions for the "Clean Atlantic" and the "Antarctic" air masses look very similar with mode diameters between 200 and $300 \mathrm{~nm}$ vacuum aerodynamic diameter $d_{\mathrm{va}}$, although mass concentrations for "Antarctic" are slightly higher. Additional modes may exist around $150 \mathrm{~nm}$ in the "Clean Atlantic" size distribution and around 350 and $700 \mathrm{~nm}$ in the "Antarctic" size distribution, however these features in the data are not very significant. The size distribution for 'South America' shows a bimodal size distribution with one mode in the same size range as the maximum of the two size distributions mentioned before. The dominant mode for this distribution has its maximum at $200 \mathrm{~nm}$ diameter. This additional mode could be a continental contribution of either nearby combustion from coastal areas or fishing boats. Unfortunately, mass concentrations for "organics" were to low to make use of the HOA/OOA analysis method (Zhang et al., 2005) or for the calculation of significant mass size distributions of typical HOA masses $(\mathrm{m} / \mathrm{z} 43$, $44,55,57)$.

The size distribution for the phytoplankton bloom period looks different from the other distributions, with a tail towards small particles - possibly from additional modes in the size range $90-200 \mathrm{~nm}$ - and a maximum between 300 and $400 \mathrm{~nm}$. Interestingly, for particle sizes above the maximum the distribution is similar to the one from the "Antarctic" period. Possible reasons are a mixing of aged continental and oceanic aerosol together with freshly created particles from within the "Bloom" region. However, mass concentrations for this distribution are within the range of the ones mentioned before.

The only averaged size distribution for "sulfate" that is clearly shifted towards larger diameters with a maximum around $500 \mathrm{~nm} d_{\mathrm{va}}$ is the one for the "Outflow Africa" time interval (Fig. 9). The shape seems to be similar to that of the "Bloom" size distribution, but the mass concentrations are approximately five times larger than for the other distributions. This could be a sign for an aged aerosol leading to a shift in the size distribution indicating a continental influence for this period. 


\section{Discussion}

Unlike the studies of Bates et al. (2005) and Phinney et al. (2006), who operated also an Aerodyne AMS on a ship, the main interest of our measurements was not continental outflow or the influence of an iron enrichment experiment, but instead the characterization of the pristine, remote marine boundary layer aerosol. Our measurements show not only that "sulfate" is the most abundant species, but even more they suggest that it is present as sulfuric acid in the aerosol phase within the remote boundary layer, similar to the findings by Phinney et al. (2006). These aerosol particles can then become very effective cloud condensation nuclei $(\mathrm{CCN})$ having an impact on cloud coverage and therefore on the global climate system (Charlson et al., 1987).

As proposed by von Glasow and Crutzen (2004), our measurements show that part of the oxidized DMS is present in the aerosol phase as MSA. Although Murphy et al. (1998) had some indications for MSA, it was impossible for them to clearly identify it in their measurements due to the limitations of their instrument. The same is true for measurements by Coe et al. (2006), which were limited by unitary resolution of the mass spectra due to the use of a quadrupole mass spectrometer as analyzer. Gieray et al. (1997) did identify methane sulfonate, the neutralized ion of methanesulfonic acid, most likely because they took samples at a remote coastal area and the aerosol had been neutralized by the time it was analyzed.

Topping et al. (2004) did not identify MSA from their online aerosol mass spectrometric measurements. However, results from ion chromatographic analysis of the $\mathrm{PM}_{10}$ concentrations presented by them also show a ratio of ten to one for sulfate and MSA, similar to our findings.

The mass concentrations of sulfate and MSA found by Phinney et al. (2006) are two to four times higher than the ones found during the OOMPH campaign, a difference that could be due to differences in phytoplankton activity or the bloom area. Their study took place in the northern Pacific Ocean whereas our measurements were located in the Southern Atlantic and Indian Ocean, although their study also took place in the summer (July 2002). However, their sulfate-toMSA ratio is within the same range as the one seen during our bloom period. Furthermore, they also observed that there was not sufficient ammonium present to neutralize the measured sulfate mass concentrations and therefore assumed a collection efficiency close to one.

Limited to the Southern Hemisphere our measurements are within the values that have been reported before. Minikin et al. (1998) found mean MSA concentrations at three different stations on Antarctica between 57 and $96 \mathrm{ng} \mathrm{m}^{-3}$ for February decreasing to 41 to $68 \mathrm{ng} \mathrm{m}^{-3}$ in March (monthly means) with MSA to nss-sulfate ratios between 0.2 and 0.4. Bürgermeister and Georgii (1991) have shown that there seems to be a strong latitudinal dependence with MSA concentrations increasing towards higher latitudes. Furthermore, while observed MSA and sulfate concentrations during winter seem to be quite similar for different years $\left(2 \mathrm{ng} \mathrm{m}^{-3}\right.$ and $23 \mathrm{ng} \mathrm{m}^{-3}$ respectively at Dumont d'Urville Station, coastal Antarctica), for summer values a large interannual variability was observed with values between $35-73 \mathrm{ng} \mathrm{m}^{-3}$ for MSA and $182-247 \mathrm{ng} \mathrm{m}^{-3}$ for nss-sulfate (Preunkert et al., 2007).

Apparently the MSA to nss-sulfate ratio seems to vary significantly depending on seasonal and geographical conditions. Another study shows that for three different Antarctic stations MSA to nss-sulfate ratios change between approximately 0.02 and 0.42 (Dumont D'Urville Station, 19911996), 0.02 and 0.8 (Neumayer Station, 1983-1995) and 0.02 - 0.6 (Halley Research Station, 1991-1993) respectively (Legrand and Pasteur, 1998).

Taking into account the large variation within MSA and sulfate concentrations and ratios the results of our study are within the range of previous findings. For the Indian Ocean Saltzman et al. (1983) reported nss-sulfate concentrations between $0.05 \mu \mathrm{g} \mathrm{m}^{-3}$ and $0.84 \mu \mathrm{g} \mathrm{m}^{-3}$ with corresponding MSA concentrations between $0.01 \mu \mathrm{g} \mathrm{m}^{-3}$ and $0.04 \mu \mathrm{g} \mathrm{m}^{-3}$, leading to MSA to sulfate ratios between 0.01 and 0.12 and agreeing well with our results.

Organic compounds are present all the time, but at very low concentrations $\left(\sim 20 \mathrm{ng} \mathrm{m}^{-3}\right)$. "Organics" observations are higher only when close to coastal areas, within air masses influenced by continental outflow or when measuring ship exhaust. Since Bates et al. (2005) focused on continental outflow, it is not surprising that their measurements showed a dominance of organic aerosols.

Unlike the ATOFMS used by Dall'Osto et al. (2004) the Aerodyne AMS is not appropriate for measuring sea salt in aerosol particles because the vaporization occurs at relatively low temperatures and because the AMS is designed to measure the submicron aerosol particle fraction between $70 \mathrm{~nm}$ and $700 \mathrm{~nm}$. However, our measurements show that the fraction of chloride measured is sufficient to correlate with wind speed and to show at least qualitatively that the fraction of sea salt in the submicron aerosol of the MBL is increasing with increasing wind velocity.

\section{Summary}

The Time-of-Flight Aerosol Mass Spectrometer (ToF-AMS) was for the first time successfully operated on a ship measuring the composition of the sub-micron marine boundary layer aerosol in the Southern Hemisphere. Time series and averaged mass concentrations for the AMS standard species "sulfate", ammonium, nitrate, chloride and "organics" could be extracted from the data improving knowledge of the nonrefractory aerosol composition from non-continental Southern Hemisphere regions. Furthermore, using the high resolution data provided by the HR-ToF-AMS (DeCarlo et al., 2006) information on methanesulfonic acid (MSA) could be directly - i.e. by physical separation from other species 
fragments at the same $m / z$ - extracted from the data after extensive laboratory characterization experiments and the development of a new data processing method. The MSA results presented here not only show the capability of the Aerodyne HR-ToF-AMS to measure individual compounds in particles, but also the limitations of the instrument. Even by using the high resolution data it will not be possible to extract information on every individual species or fragment, even if it is present in sufficient concentrations to be detected with the instrument. Nevertheless, with careful analysis and laboratory studies the high-resolution data can greatly improve the results that can be obtained by an AMS, not only by delivering information about species that could not be previously physically separated from the standard AMS data with unit-resolution spectra, but also by significantly improved detection limits for selected species.

During most of the campaign, AMS "sulfate" made up two thirds of the total mass in the size range measured. Based on the results presented above a large fraction of the AMS "sulfate" is indeed sulfuric acid. Interestingly, the second-most prominent non-refractory aerosol species after sulfate or sulfuric acid seems to be MSA. MSA is almost always present when the observed air masses are coming from oceanic regions. The aerosol mass concentrations for this species are approximately ten times lower than for "sulfate". However, for oceanic sources MSA has an abundance similar to the sum of all other organic species. Mass concentrations for "organics", besides MSA, are very low nearly all the time on the ocean except in coastal regions, indicating their continental origin. Only during the phytoplankton bloom event, when concentrations of organic compounds rose by a factor of 20 compared to the oceanic background, a direct link between particle phase "organics" and oceanic sources is suggested. This possible connection between organic vapors emitted by the ocean and particulate organics is the subject of further investigations.

Acknowledgements. This research was supported by the OOMPH (Organics over the Ocean Modifying Particles in both Hemispheres) project of the EU Sixth Framework Programme. We would like to thank T. Böttger and the crew of the Marion Dufresne for logistical support, and J. Williams, Co-Ordinator of the OOMPH procect, for making it possible for us to participate in this project. Thanks to J. Sciare for sharing his PILS-IC data and to H. Wernli for back trajectory data. We also thank the German Weather Service (DWD) for providing access to the ECMWF analysis data used for the trajectory calculations. Special thanks to the Institut Polaire Français Paul Émile Victor (IPEV) for funding of our participation in the cruise through the IPEV-AEROTRACE program and for providing sea surface temperature and wind data. S. Zorn also thanks the German Research Foundation (DFG) for financing his work through the Research Training School GRK 826. T. Hoffmann and M. Schott acknowledge financial support from the EU project MAP (Marine Aerosol Production).

Edited by: V. F. McNeill

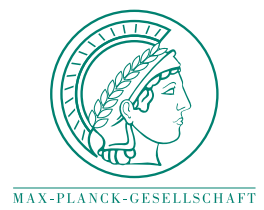

The publication of this article is financed by the Max Planck Society.

\section{References}

Allan, J. D., Delia, A. E., Coe, H., Bower, K. N., Alfarra, M. R., Jimenez, J. L., Middlebrook, A. M., Drewnick, F., Onasch, T. B., Canagaratna, M. R., Jayne, J. T., and Worsnop, D. R.: A generalised method for the extraction of chemically resolved mass spectra from aerodyne aerosol mass spectrometer data, J. Aerosol Sci., 35, 909-922, 2004.

Allen, A. G., Dick, A. L., and Davison, B. M.: Sources of atmospheric methanesulphonate, non-sea-salt sulphate, nitrate and related species over the temperate south pacific, Atmos. Environ., 31, 191-205, 1997.

Barnes, I., Hjorth, J., and Mihalopoulos, N.: Dimethyl sulfide and dimethyl sulfoxide and their oxidation in the atmosphere, Chem. Rev., 106, 940-975, 2006.

Bates, T. S., Quinn, P. K., Coffman, D. J., Johnson, J. E., and Middlebrook, A. M.: Dominance of organic aerosols in the marine boundary layer over the Gulf of Maine during NEAQS 2002 and their role in aerosol light scattering, J. Geophys. Res., 110, D18202, doi:10.1029/2005JD005797, 2005.

Berresheim, H.: Biogenioc sulfur emissions from the subantarctic and antarctic ocean, J. Geophys. Res.-Atmos., 92, 13245 $13262,1987$.

Berresheim, H., Elste, T., Tremmel, H. G., Allen, A. G., Hansson, H. C., Rosman, K., Dal Maso, M., Makela, J. M., Kulmala, M., and O'Dowd, C. D.: Gas-aerosol relationships of H2SO4, MSA, and $\mathrm{OH}$ : Observations in the coastal marine boundary layer at mace head, ireland, J. Geophys. Res.-Atmos., 10(12), 8100, 2002.

Bonsang, B., Polle, C., and Lambert, G.: Evidence for marine production of isoprene, Geophys. Res. Lett., 19, 1129-1132, 1992.

Brandini, F. P., Boltovskoy, D., Piola, A., Kocmur, S., Rottgers, R., Abreu, P. C., and Lopes, R. M.: Multiannual trends in fronts and distribution of nutrients and chlorophyll in the southwestern atlantic (30-62 ${ }^{\circ}$ s), Deep-Sea Res. Part I-Oceanogr. Res. Pap., 47, 1015-1033, 2000.

Bürgermeister, S. and Georgii, H. W.: Distribution of methanesulfonate, nss sulfate and dimethylsulfide over the atlantic and the north-sea, Atmospheric Environment Part a-General Topics, 25, 587-595, 1991.

Charlson, R. J., Lovelock, J. E., Andreae, M. O., and Warren, S. G.: Oceanic phytoplankton, atmospheric sulphur, cloud albedo and climate, Nature, 326, 655-661, 1987.

Chasteen, T. G. and Bentley, R.: Volatile Organic Sulfur Compounds of Environmental Interest: Dimethyl Sulfide and Methanethiol. An Introductory Overview, J. Chem. Educ., 81, 1524-1528, 2004.

Coe, H., Allan, J. D., Alfarra, M. R., Bower, K. N., Flynn, M. J., McFiggans, G. B., Topping, D. O., Williams, P. I., O’Dowd, C. D., Dall'Osto, M., Beddows, D. C. S., and Harrison, R. M.: Chemical and physical characteristics of aerosol particles at a remote coastal location, Mace Head, Ireland, during NAMBLEX, 
Atmos. Chem. Phys., 6, 3289-3301, 2006,

http://www.atmos-chem-phys.net/6/3289/2006/.

Dall'Osto, M., Beddows, D. C. S., Kinnersley, R. P., Harrison, R. M., Donovan, R. J., and Heal, M. R.: Characterization of individual airborne particles by using aerosol time-of-flight mass spectrometry at Mace Head, Ireland, J. Geophys. Res., 109, D21302, doi:10.1029/2004JD004747, 2004.

DeCarlo, P. F., Kimmel, J. R., Trimborn, A., Northway, M. J., Jayne, J. T., Aiken, A. C., Gonin, M., Fuhrer, K., Horvath, T., Docherty, K. S., Worsnop,, D. R., and Jimenez, J. L.: Field-Deployable, High-Resolution, Time-of-Flight Aerosol Mass Spectrometer, Anal. Chem., 78, 8281-8289, 2006.

Drewnick, F., Hings, S. S., DeCarlo, P. F., Jayne, J. T., Gonin, M., Fuhrer, K., Weimer, S., Jimenez, J. L., Demerjian, K. L., Borrmann, S., and Worsnop, D. R.: A New Time-of-Flight Aerosol Mass Spectrometer (TOF-AMS) - Instrument Description and First Field Deployment, Aerosol Sci. Technol., 39, 637-658, 2005.

Garzoli, S. L.: Geostrophic velocity and transport variability in the brazil malvinas confluence, Deep-Sea Res. Part I-Oceanogr. Res. Pap., 40, 1379-1403, 1993.

Gieray, R., Wieser, P., Engelhardt, T., Swietlicki, E., Hansson, H.C., Mentes, B., Orsini, D., Martinsson, B., Svenningsson, B., Noone, K. J., and Heintzenberg, J.: Phase Partitioning of Aerosol Constituents in Cloud Based on Single-Particle and Bulk Analysis, Atmos. Environ., 31, 2491-2502, 1997.

Hinds, W. C.: Aerosol Technology: Properties, Behavior and Measurment of Airborne Particles, 2nd ed., Wiley-Interscience, 1998.

Hings, S. S., Walter, S., Schneider, J., Borrmann, S., and Drewnick, F.: Comparison of a quadrupole and a time-of-flight aerosol mass spectrometer during the Feldberg aerosol characterization experiment 2004, Aerosol Sci. Technol., 41, 679-691, 2007.

Huffman, J. A., Jayne, J. T., Drewnick, F., Aiken, A. C., Onasch, T., Worsnop, D. R., and Jimenez, J. L.: Design, modeling, optimization, and experimental tests of a particle beam width probe for the aerodyne aerosol mass spectrometer, Aerosol Sci. Technol., 39, 1143-1163, 2005.

IPCC, 2007: Climate Change 2007: The Physical Science Basis, in: Contribution of Working Group I to the Fourth Assessment Report of the Intergovernmental Panel on Climate Change, edited by: Solomon, S., Qin, D., Manning, M., Chen, Z., Marquis, M., Averyt, K. B., Tignor, M., and Miller, H. L., Cambridge University Press, Cambridge, United Kingdom and New York, NY, USA, 996 pp., 2007.

Jayne, J. T., Leard, D. C., Zhang, X. F., Davidovits, P., Smith, K. A., Kolb, C. E., and Worsnop, D. R.: Development of an aerosol mass spectrometer for size and composition analysis of submicron particles, Aerosol Sci. Technol., 33, 49-70, 2000.

Kerminen, V. M., Aurela, M., Hillamo, R. E., and Virkkula, A.: Formation of particulate msa: Deductions from size distribution measurements in the finnish arctic, Tellus Series B-Chemical and Physical Meteorology, 49, 159-171, 1997.

Kolb, C. E.: Iodine's air of importance, Nature, 417, 597-598, 2002.

Kulmala, M., Korhonen, P., Napari, I., Karlsson, A., Berresheim, H., and O'Dowd, C. D.: Aerosol formation during parforce: Ternary nucleation of $\mathrm{H}_{2} \mathrm{SO}_{4}, \mathrm{NH}_{3}$, and $\mathrm{H}_{2} \mathrm{O}$, J. Geophys. Res.Atmos., 107(11), 8111, 2002.

Legeckis, R. and Gordon, A. L.: Satellite-observations of the brazil and falkland currents - 1975 to 1976 and 1978, Deep-Sea Research Part a-Oceanographic Research Papers, 29, 375-401, 1982.

Legrand, M. and Pasteur, E. C.: Methane sulfonic acid to non-seasalt sulfate ratio in coastal antarctic aerosol and surface snow, J. Geophys. Res.-Atmos., 103, 10 991-11 006, 1998.

Legrand, M. and Pasteur, E. C.: Methane sulfonic acid to non-seasalt sulfate ratio in coastal antarctic aerosol and surface snow, J. Geophys. Res.-Atmos., 103, 10 991-11 006, 1998

Li, S. M., Barrie, L. A., Talbot, R. W., Harriss, R. C., Davidson, C. I., and Jaffrezo, J. L.: Seasonal and geographic variations of methanesulfonic acid in the arctic troposphere, Atmospheric Environment Part a-General Topics, 27, 3011-3024, 1993.

Li, S. M., Barrie, L. A., and Toom, D.: Seasonal variations of methanesulfonate, non-sea-salt sulfate, and sulfur dioxide at three sites in canada, J. Geophys. Res.-Atmos., 101, 4165-4173, 1996.

Lovelock, J. E., Maggs, R. J., and Wade, R. J.: Halogenated Hydrocarbons in and over the Atlantic, Nature, 241, 194-196, 1973.

Matthew, B.M., T.B. Onasch, and A.M. Middlebrook, Collection Efficiencies in an Aerodyne Aerosol Mass Spectrometer as a Function of Particle Phase for Laboratory Generated Aerosols. Submitted to Aerosol Science and Technology, in press, 2008.

Meskhidze, N. and Nenes, A.: Phytoplankton and Cloudiness in the Southern Ocean, Science, 314, 1419-1423, 2006.

Mihalopoulos, N., Nguyen, B. C., Boissard, C., Campin, J. M., Putaud, J. P., Belviso, S., Barnes, I., and Becker, K. H.: Fieldstudy of dimethylsulfide oxidation in the boundary-layer - variations of dimethylsulfide, methanesulfonic-acid, sulfur-dioxide, non-seasalt sulfate and aitken nuclei at a coastal site, J. Atmos. Chem., 14, 459-477, 1992.

Millet, D. B., Goldstein, A. H., Allan, J. D., Bates, T. S., Boudries, H., Bower, K. N., Coe, H., Ma, Y. L., McKay, M., Quinn, P. K., Sullivan, A., Weber, R. J., and Worsnop, D. R.: Volatile organic compound measurements at trinidad head, california, during itct 2k2: Analysis of sources, atmospheric composition, and aerosol residence times, J. Geophys. Res.-Atmos., 109(16), D23S16, doi:10.1029/2003JD004026, 2004.

Minikin, A., Legrand, M., Hall, J., Wagenbach, D., Kleefeld, C., Wolff, E., Pasteur, E. C., and Ducroz, F.: Sulfur-containing species (sulfate and methanesulfonate) in coastal antarctic aerosol and precipitation, J. Geophys. Res.-Atmos., 103, 10975 $10990,1998$.

Murphy, D. M., Thomson, D. S., Middlebrook, A. M., and Schein, M. E.: In situ single-particle characterization at Cape Grim, J. Geophys. Res., 103, 16485-16491, 1998.

NIST Mass Spec Data Center: Stein, S. E., director, Mass Spectra, NIST Chemistry WebBook, NIST Standard Reference Database Number 69, edited by: Linstrom, P. J. and Mallard, W. G., National Institute of Standards and Technology, Gaithersburg MD, 20899, http://webbook.nist.gov/, 2005.

O’Dowd, C. D., Jimenez, J. L., Bahreini, R., Flagan, R. C., Seinfeld, J. H., Hameri, K., Pirjola, L., Kulmala, M., Jennings, S. G., and Hoffmann, T.: Marine aerosol formation from biogenic iodine emissions, Nature, 417, 632-636, 2002.

O’Dowd, C. D., Facchini, M. C., Cavalli, F., Ceburnis, D., Mircea, M., Decesari, S., Fuzzi, S., Yoon, Y. J., and Putaud, J. P.: Biogenically driven organic contribution to marine aerosol, Nature, 431, 676-680, 2004 
Phinney, L., Leaitch, W. R., Lohmann, U., Boudries, H., Worsnop, D. R., Jayne, J. T., Toom-Sauntry, D., Wadleigh, M., Sharma, S., and Shantz, N.: Characterization of the aerosol over the subarctic north east Pacific Ocean, Deep-Sea Res. II, 53, 2410-2433, 2006.

Preunkert, S., Legrand, M., Jourdain, B., Moulin, C., Belviso, S., Kasamatsu, N., Fukuchi, M., and Hirawake, T.: Interannual variability of dimethylsulfide in air and seawater and its atmospheric oxidation by-products (methanesulfonate and sulfate) at Dumont D’Urville, coastal Antarctica (1999-2003), J. Geophys. Res.Atmos., 112(13), D06306, doi:101.1029/2006JD007585, 2007.

Putaud, J. P., Davison, B. M., Watts, S. F., Mihalopoulos, N., Nguyen, B. C., and Hewitt, C. N.: Dimethylsulfide and its oxidation products at two sites in Brittany (France), Atmos. Environ., 33, 647-659, 1999.

Quinn, P. K., Bates, T. S., Coffman, D., Onasch, T. B., Worsnop, D., Baynard, T., de Gouw, J. A., Goldan, P. D., Kuster, W. C., Williams, E., Roberts, J. M., Lerner, B., Stohl, A., Pettersson, A., and Lovejoy, E. R.: Impacts of sources and aging on submicrometer aerosol properties in the marine boundary layer across the gulf of maine, J. Geophys. Res.-Atmos., 111(20), D23S36, doi:10.1029/2006JD007582, 2006.

Saltzman, E. S., Savoie, D. L., Zika, R. G., and Prospero, J. M.: Methane sulfonic acid in the marine atmosphere, J. Geophys. Res., 88, 10 897-10 902, 1983.

Saltzman, E. S., Savoie, D. L., Prospero, J. M., and Zika, R. G.: Atmospheric methanesulfonic-acid and non-sea-salt sulfate at fanning and american samoa, Geophys. Res. Lett., 12, 437-440, 1985

Saltzman, E. S., Savoie, D. L., Prospero, J. M., and Zika, R. G.: Methanesulfonic-acid and non-sea-salt sulfate in pacific air - regional and seasonal variations, J. Atmos. Chem., 4, 227-240, 1986
Seinfeld, J. H. and Pandis, S. N.: Atmospheric Chemistry and Physics: From Air Pollution to Climate Change, 2nd ed., WileyInterscience, 2006.

Sodemann, H., Palmer, A. S., Schwierz, C., Schwikowski, M., and Wernli, H.: The transport history of two Saharan dust events archived in an Alpine ice core, Atmos. Chem. Phys., 6, 667-688, 2006, http://www.atmos-chem-phys.net/6/667/2006/.

Topping, D., Coe, H., McFiggans, G., Burgess, R., Allan, J. D., Alfarra, M. R., Bower, K., Choularton, T. W., Decesari, S., and Facchini, M. C.: Aerosol chemical characteristics from sampling conducted on the Island of Jeju, Korea during ACE Asia, Atmos. Environ., 38, 2111-2123, 2004.

von Glasow, R. and Crutzen, P. J.: Model study of multiplephase DMS oxidation with a focus on halogens, Atmos. Chem. Phys., 4, 589-608, 2004, http://www.atmos-chem-phys.net/4/589/2004/.

Warneck, P.: Chemistry of the natural atmosphere, in: International Geophysics Series, Academic Press Inc., 41(7), 278-373, 1988.

Watts, S. F., Watson, A., and Brimblecombe, P.: Measurements of the aerosol concentrations of methanesulfonic acid, dimethyl sulfoxide and dimethyl sulfone in the marine atmosphere of the british isles, Atmos. Environ., 21, 2667-2672, 1987.

Wernli, H. and Davies, H. C.: A lagrangian-based analysis of extratropical cyclones. I: The method and some applications, Q. J. Roy. Meteor. Soc., 123, 467-489, 1997.

Wu, J.: Oceanic whitecaps and sea state, J. Phys. Oceanogr., 9, 1064-1068, 1979.

Zhang, Q., Alfarra, M. R., Worsnop, D. R., Allan, J. D., Coe, H., Canagaratna, M. R., and Jimenez, J. L.: Deconvolution and quantification of hydrocarbon-like and oxygenated organic aerosols based on aerosol mass spectrometry, Environ. Sci. Technol., 39, 4938-4952, 2005. 